Finance and Economics Discussion Series Divisions of Research \& Statistics and Monetary Affairs Federal Reserve Board, Washington, D.C.

\title{
Market Discipline in Banking Reconsidered: The Roles of Funding Manager Decisions and Deposit Insurance Reform
}

\section{Daniel M. Covitz, Diana Hancock, and Myron L. Kwast \\ 2004-53}

NOTE: Staff working papers in the Finance and Economics Discussion Series (FEDS) are preliminary materials circulated to stimulate discussion and critical comment. The analysis and conclusions set forth are those of the authors and do not indicate concurrence by other members of the research staff or the Board of Governors.

References in publications to the Finance and Economics Discussion Series (other than acknowledgement) should be cleared with the author(s) to protect the tentative character of these papers. 


\title{
MARKET DISCIPLINE IN BANKING RECONSIDERED: THE ROLES OF FUNDING MANAGER DECISIONS AND DEPOSIT INSURANCE REFORM
}

\author{
Daniel M. Covitz, Diana Hancock, Myron L. Kwast ${ }^{\dagger}$ \\ Board of Governors of the Federal Reserve System, Washington, DC 20551
}

August 2004

\begin{abstract}
We find that the risk-sensitivity of bank holding company subordinated debt spreads at issuance increased with regulatory reforms that were designed to reduce conjectural government guarantees, but declined somewhat with subsequent reforms that were aimed in part at reducing regulatory forbearance. In addition, we test and find evidence for a straightforward form of "market discipline:” The extent to which bond issuance penalizes relatively risky banks. Evidence for such discipline only appears in the periods after conjectural government guarantees were reduced.
\end{abstract}

$\dagger$ The views expressed are those of the authors and do not necessarily reflect those of the Board of Governors of the Federal Reserve System or its staff. The authors thank Harald Benink, Robert Bliss, Douglas Evanoff, Mark Flannery, David Llewellin, Kevin Stiroh, session participants at the Risk and Stability in the Financial System Conference hosted by Bocconi University and the Bank for International Settlements and session participants at the Bank of England and Research Task Force of the Basel Committee workshop on "The Use of Market Data to Assess Bank Risk and Banking System Risk" for their valuable comments and suggestions. The authors also thank Matthew Cox and Laura Kawano for their outstanding research assistance. All errors remain those of the authors. 


\section{INTRODUCTION}

It is conventional wisdom that subordinated debt investors became sensitive to banking organization default risks when regulators stopped protecting large bank holding companies’ creditors. The evidence in support of this view is that subordinated debt spreads were not correlated with bank specific risks until after regulatory reforms were put in place to eliminate "too-big-tofail” (TBTF) protection for subordinated debt holders. 1, 2, 3

Despite this conventional wisdom, there is some evidence that subordinated debt investors were sensitive to risks in the mid-1980s. For example, using pricing information from the primary bond market and a sample selection model, Covitz, Hancock, and Kwast (2004) demonstrated that perceived government guarantees during 1985-1988 did not make subordinated debt investors completely insensitive to bank-specific risks. They found a statistically significant positive relationship between risk proxies and banking organization subordinated debt issuance (primary) market spreads over comparable maturity Treasury securities. ${ }^{4}$ In addition, Goyal (2001) reports that U.S. banking organizations with greater risk-taking incentives (i.e., organizations with low $q$ ratios) were more likely to issue subordinated debentures with ex ante restrictive covenants (e.g., restrictions on a bank’s investment policies, restrictions on financing policies, and restrictions on

\footnotetext{
${ }^{1}$ The quintessential "case study" for this view is the July 1984 decision by the Federal Deposit Insurance Corporation to save Continental Illinois Bank by providing “open bank assistance.” This was accomplished by purchasing a billion dollars of preferred stock in the parent holding company, which was immediately downstreamed to the bank as common equity. Flannery and Sorescu (1996, pp. 1352-1353) argue that this direct capital infusion into the parent holding company essentially protected investors that held subordinated debentures of the parent holding company. Comments by the Comptroller of the Currency supporting the existence of a too-big-tofail policy for other banks no doubt further encouraged such investor perceptions. Flannery (1998) refers to the 1984-1989 period as the too-big-to-fail (TBTF) period, while Jagtiani, Kaufman and Lemieux (2002) refer to it as the de facto protection period for uninsured deposits and other debt.

${ }^{2}$ Studies using data from 1983-1984 (e.g., Avery, Belton and Goldberg (1988) and Gorton and Santomero (1990)) and from 1985-1988 (e.g., Flannery and Sorescu (1996)) found no significant effect of accounting risk measures on banking organization subordinated debt spreads. These results have been interpreted as prima facie evidence that the decade of the 1980s was characterized by considerable de facto "too-big-to-fail" (TBTF) protection for subordinated debt holders.
}

${ }^{3}$ See, for example, De Young, Flannery, Lang and Sorescu (2001), Hancock and Kwast (2001), Morgan and Stiroh (2001), Jagtiani, Kaufman, and Lemieux (2002), and Covitz, Hancock and Kwast (2004).

${ }^{4}$ This finding is consistent with early studies in the market discipline literature (Hannan and Hanweck (1988) and Ellis and Flannery (1992)) that found interest rates on relatively bankruptcy remote large certificates of deposit to be sensitive to bank-specific risks. 
the payment of dividends) in the 1981-1988 period, than they were in the 1989-1995 period. ${ }^{5}$

Some market discipline research has recently shifted towards both assessing the degree of risk-sensitivity of debt spreads and determining whether investors are “tough enough.” For example, researchers have considered whether the risk-sensitivity of bank debt spreads is similar to the risksensitivity of other corporate debt spreads. Morgan and Stiroh (1999) found that the relationship between issuance market bond spreads and bond ratings was about the same for banks as it was for other corporate firms. ${ }^{6}$ Other researchers have focused on whether pricing signals derived from secondary market data have been sufficient to influence (voluntary) actions taken by management. Using secondary bond market information from 1985-1997, Bliss and Flannery (2001) considered whether sharp losses on firm-specific excess return indices for outstanding bonds issued by U.S. banking organizations are typically followed by managerial actions, including changes in leverage, asset risk, and reliance on uninsured liabilities. Consistent with their expectation that market discipline was being exerted, they were able to detect some changes in managerial actions following such losses. However, they did not find evidence that such actions ultimately led to an increase in security values.

In this paper, we attempt to integrate these strands of research by extending the analysis of Covitz, Hancock and Kwast (2004) to explore the degree to which the sensitivity of subordinated debt spreads to accounting-based measures of risk (henceforth referred to as the observed risksensitivity) has changed across different deposit insurance/regulatory regimes. We recognize at the outset that observed subordinated debt spreads would likely reflect investor perceptions with respect both to the probability of default (PD) and to potential losses given default (LGD). Deposit insurance reforms that are designed to reduce conjectural government guarantees, or to lower the liquidation standing of uninsured creditors, are expected to increase the risk-sensitivity of subordinated debt spreads. But, reforms aimed at deterring regulatory forbearance, such as prompt corrective actions (PCA), could potentially reduce the probability of default (PD) or reduce the expected losses borne by subordinated investors in the event of default (LGD) because resolutions

\footnotetext{
${ }^{5}$ Goyal argues that the regulatory capital guidelines implemented after the 1988 Basel Capital Accord placed significant constraints on a bank's ability to use debt contracts that contained ex ante restrictive covenants as counting towards regulatory capital. In the post Basel Accord regime, the relationship between restrictive covenants and banking organization $q$ ratios has not been statistically significant.

${ }^{6}$ These authors also report that this relationship was weaker for bigger and for less transparent banks than it was for other banks.
} 
would be more timely and would be resolved at lower cost. ${ }^{7}$ Such reforms are expected, ceteris paribus, to lower the observed risk-sensitivity of subordinated debt spreads.

Our analysis considers three deposit insurance/regulatory regimes: de facto TBTF (19851987); purchase and assumption (1988-1992); and, post-FDICIA (1993-2002). ${ }^{8}$ Beginning in the late 1980s the Federal Deposit Insurance Corporation (FDIC) installed mechanisms (e.g., purchase and assumption transactions) by which it could rescue an insured bank subsidiary without protecting the holding company, or even all of the creditors of the insured bank. ${ }^{9}$ Perhaps more important, legislative changes in the early 1990s made very clear Congress' intent that the FDIC should treat subordinated debt holders' claims, both at the bank and the holding company level, as secondary to those of depositors. The Federal Deposit Insurance Corporation Improvement Act (FDICIA) of 1991 required least cost (to the FDIC) resolutions of failed depositories and established the system of prompt corrective actions to be taken toward troubled banks. And, the National Depositor Preference Act of 1993 established a clear priority for the distribution of (unsecured) claims realized from the liquidation or other resolution of an insured depository.

By way of preview, we demonstrate that bank subordinated debt spreads were sensitive to banking organization-specific risks in all three deposit insurance regulatory regimes. Consistent with the spirit of the conventional wisdom, we find that the observed risk-sensitivity of issuance market subordinated debt spreads increased between the de facto TBTF and the purchase and assumption regimes. And, in contrast to the conventional wisdom, we find that the risk-sensitivity of issuance market subordinated debt spreads, although still statistically significant, declined after the implementation of PCA reforms. This finding suggests that investors perceived PCA rules would limit the downside risk to uninsured creditors.

\footnotetext{
${ }^{7}$ The PCA system imposes increasingly severe actions on undercapitalized banking organizations as their capital ratios decline, including restrictions on deposit interest rates, elimination of brokered deposits, restrictions on asset growth, restrictions on inter-affiliate transactions, and required approvals for acquisitions, branching, and new activities. Under PCA criteria, critically undercapitalized banks, defined as those with tangible equity capital less than 2 percent of total assets, must be placed in receivership within 90 days, unless such actions would not achieve the purposes of PCA, or within one year, unless specific statutory requirements are met. Also under PCA, 60 days after a bank is determined to be critically undercapitalized, it cannot make payments on subordinated debt without regulatory approval.

${ }^{8}$ The PCA system required by FDICIA was implemented in December 1992. See Jones and King (1995).

${ }^{9}$ See, for example, Flannery and Sorescu (1996, pp. 1352-1353). In addition, under the Financial Institutions Reform, Recovery, and Enforcement Act of 1989 (FIRREA), the FDIC may apportion losses among all of the banks within a multibank holding company in the event that one or more of the related banks fail.
} 
A second goal of this paper is to analyze whether the risk-sensitivity of primary market subordinated debt spreads was sufficient in each of the three deposit insurance/regulatory regimes to effectively and constructively augment regulatory controls by penalizing relatively risky banking organizations that would issue subordinated debt. We use a strightforward measure of this form of market discipline that has also been used to study non-financial firms: The extent to which relatively risky banking organizations were deterred from issuing debt. ${ }^{10}$ This measure of market discipline has several advantages over the measures that were considered in Bliss and Flannery (2002). First, issuance decisions can be measured without noise. Second, bond issuance is clearly the result of an explicit decision by bank management. Third, the action taken (i.e., not to issue debt) implies ceteris paribus, a reduction in leverage and a corresponding reduction in banking organization-specific risk.

Our analysis finds evidence of market discipline having been imposed via the issuance decision on relatively risky banking organizations in all but the first (i.e., the de facto TBTF) deposit insurance regime. Thus it appears that subordinated debt investors have been "tough enough" to impose market discipline once government conjectural guarantees were substantially reduced. Of course, this type of market discipline may ultimately be a weak influence on the portfolio decisions of the bank managers, as there are other funding sources available to banking organizations (e.g., brokered deposits). But, if banking organizations were required to issue subordinated debt, this type of market discipline would have more of an impact. Regardless, our finding of market discipline is the first evidence that the bank subordinated debt market is "tough enough" to directly influence managerial actions. ${ }^{11}$

The paper proceeds as follows. Section II provides the intuition behind using issuance decision information to gauge market discipline present in each deposit insurance regime. Section III specifies an empirical issuance decision model for funding managers at large U.S. banking organizations with respect to subordinated notes and debentures. Section IV employs this issuance decision model in the specification of the sample selection model used to analyze whether the risk sensitivity of observed issuance spreads on subordinated debt instruments changed across deposit

${ }^{10}$ See, for example, Jung, Kim, and Stulz (1996), Castanias (1983), and Marsh (1982).

${ }^{11}$ Morgan and Stiroh (2001) find evidence that the pricing in the bank subordinated debt market is similar to that for nonfinancial bonds. However, there is no direct measure of whether the bond market influences any actions taken by bank managers. 
insurance regimes. Section $\mathrm{V}$ presents parameter estimates for the issuance decision model and for the sample selection model for the deposit insurance/regulatory regimes under consideration. Section VI draws inferences from the estimated models about the credit-risk-sensitivity of subordinated debt spreads under different regimes and reinterprets the findings of previous market discipline studies.

\section{Defining AND TeSTing For MARKet Discipline}

The definition of market discipline has evolved gradually over the last two decades from just considering the risk sensitivity of debt prices and spreads to accounting for the effects of this risk sensitivity on managerial decisions. Adopting this more recent approach, we define market discipline in terms of the incentives provided to bank managers by the debt issuance market. Importantly, this definition also provides straightforward intuitive guidance for interpreting our empirical results and, more generally, for identifying financial environments in which bond market discipline exists. Consider the following definition:

DEFINITION: The bond market exerts market discipline during periods when conditions are such that the bond issuance market "penalizes" relatively risky banks.

In our definition, both the bond issuance decision by bank managers and the risk premium demanded by bond investors play central roles. We identify three distinct cases in order to provide guidance for interpreting our results. When formulating the cases, we envision banking organizations differing at a point in time according to their portfolio risk, with riskier portfolios offering higher expected returns; and we envision investors differing across time by the size of the risk premiums demanded for a given level of observable risk. Such premiums can vary over time because conjectural guarantees alter the relationship between observable risk and actual risk to the investor, and also because bond market conditions vary.

First, consider the case where government conjectural guarantees are strong. In this situation, the expected losses on a bank's portfolio should have little, in any, influence on the risk premium demanded in the issuance market by (government protected) bond investors. Thus, measures of individual firm risk should have little or perhaps even no influence on observed bond issuance spreads. In addition, and building on Merton's (1977) insight that deposit insurance (government guarantees) can be viewed as a put option on the deposit insurer, strong government guarantees would provide an incentive for relatively risky banks to issue subordinated debt, because 
riskier banks would benefit most from the government subsidy. Put differently, in such a world we would expect to observe a positive correlation between a bank's bond issuance decision and measures of its risk. In such an environment, the bond market clearly does not deter banks from taking on risk, and our definition would indicate that market discipline does not exist.

Now consider the case where government guarantees are not particularly strong (or even nonexistent) and the risk premium demanded by bond investors is just large enough to cover their expected losses. In this situation, measures of individual firm risk should be positively correlated with observed bond issuance spreads. In addition, and in contrast with the case where government guarantees are strong, in this environment we should expect to observe that the firm's bond issuance decision is not affected by measures of the bank's portfolio risk. This is because both risky and safe firms would have expected returns that would compensate for their relative risks, and therefore, both risky and safe firms should have similar incentives to issue subordinated debt. In this case, because risk taking is not deterred even though there is a positive correlation between observed debt issuance spreads and measures of individual bank risk, there is no market discipline.

Lastly, consider a third case where government guarantees are not particularly strong (or even nonexistent) and the risk premiums demanded by (possibly very risk averse) bond investors are very high. ${ }^{12}$ Such a situation can occur, for example, if there is great uncertainty regarding a bank's prospects and during periods of overall market turmoil. Here, measures of individual firm risk should be positively correlated with observed bond issuance spreads, perhaps even more positively correlated than in the previous case. In addition, in this environment we should expect to observe that the bank's bond issuance decision is affected by measures of the firm's portfolio risk, since banks with higher observable risk are not likely to have sufficiently high expected returns to compensate for the elevated risk-premiums. Therefore, it would be likely that relatively risky banks would be observed to be deterred from issuing debt because bond investors demand a punitive premium for bearing risk. In this case, our definition would clearly say that market discipline exists.

To sum up, this discussion suggests some straightforward guidelines for testing for market discipline. First, if government guarantees (the deposit insurance regime) dominate the issuance market environment, measures of individual bank risk should, ceteris paribus, be positively

\footnotetext{
12 The decomposition of spreads into a component that covers expected losses and a risk premium is standard in the empirical finance literature. See, for example, Jones, Gruber, Agrawal and Mann (2001).
} 
correlated with bank issuance decisions and uncorrelated with issuance spreads. In this case, there is no market discipline. Second, if government guarantees do not dominate but private investors only ask to be compensated for expected losses, measures of individual bank risk should, ceteris paribus, be independent of bank issuance decisions and positively correlated with issuance spreads. In this case, there is no market discipline. Third, if government guarantees do not dominate but private investors ask to be more than compensated for expected losses, measures of individual bank risk should, ceteris paribus, be negatively correlated with bank issuance decisions and positively correlated with issuance spreads. In this case, market discipline exists.

\section{AN ISSUANCE DECISION MODEL FOR SUbORDINATED DEBENTURES}

It is widely recognized that firms gauge the market carefully in order to choose an opportune time to issue debt. ${ }^{13}$ Starting in 1982, the Securities and Exchange Commission allowed firms to register securities in advance of issuance under Rule 415. Shelf registrations allow firms considerable flexibility in the timing of their debt issuance. ${ }^{14}$ Securities "on the shelf” not only enable firms to require investment bankers to bid competitively, but also allow firms to refuse to sell when desirable bids for their securities are not forthcoming.

Banking organizations, like other corporate entities, may reduce their reliance on debt when their default probability rises. ${ }^{15}$ If expected funding costs are sufficiently risk-sensitive, then riskier banking organizations may be less likely to issue subordinated debt instruments. ${ }^{16,17}$

To measure the expected default probability of a given banking organization, several publicly available risk proxies, which have been used in previous bank market discipline studies, are examined. These include the ratio of non-accruing loans to total assets $\left(N A T A_{i t}\right)$, the ratio of

\footnotetext{
${ }^{13}$ See Covitz and Harrison (2003) for a discussion about why banking organizations strategically time their public bond issues and evidence that they do so.

${ }^{14}$ With a shelf registration, securities can be sold up to two years later.

${ }^{15}$ Jung, Kim, and Stulz (1996) note that financial distress and bankruptcy become more likely as debt and firm risk increase. See also Castanias (1983) and Marsh (1982).

${ }^{16}$ See Board of Governors of the Federal Reserve System (1999b) and Board of Governors of the Federal Reserve System and United States Department of Treasury (2000, p.36).

${ }^{17}$ Birchler and Hancock (2004) provide a model where a banking organization would issue subordinated debt upon the receipt of "good" news and would issue senior debt upon the receipt of "bad" news to separate investors with different, yet unobservable, beliefs on the probability of its failure.
} 
accruing loans past due 90 days or more to total assets $\left(P D T A_{i t}\right)$, the ratio of other real estate owned to total assets $\left(O R E O_{i t}\right)$, the absolute value of the difference between assets and liabilities maturing or repricing within one year as a proportion of equity value $\left(A G A P_{i t}\right)$, and the ratio of total book liabilities to the sum of the market value of common stock and the book value of preferred stock $\left(M A R K E T L E V_{i t}\right) .{ }^{18}$ Higher values for these proxies should reflect greater default risk and/or signal a deteriorating financial condition for the banking organization.

Moreover, when economic conditions deteriorate, it stands to reason that fewer positive net present value projects may require external debt finance. ${ }^{19}$ Several proxies are used to assess the effects of business conditions on banking organization debt issuance decisions. First, poor current macroeconomic conditions may curtail the growth prospects of many firms simultaneously. Thus, a relatively high unemployment rate (UE) could be a harbinger of retrenchment in debt issuance activities by the corporate sector. ${ }^{20}$ Second, because stock market excess returns have been found to be negatively correlated with contemporaneous investment (Lamont (2000)) and positively correlated with subsequent corporate investment (Fama (1981), Fischer and Merton (1984), and Barro (1990)), it is likely that corporate debt issuance would also be negatively correlated with

\footnotetext{
${ }^{18}$ See, for example, Flannery and Sorescu (1996) and DeYoung et al. (2001). Balance sheet and income statement data are from consolidated financial statements for bank holding companies (FR Y-9C). These items are reported as of the close of business on the last calendar day of the quarter. Data on the market value of common stock are from the Center for Research in Security Prices (CRSP) tape published by the University of Chicago Graduate School of Business. Both sets of data are publicly available.

${ }^{19}$ Jung, Kim, and Stulz (1996, p. 171), for example, report that investment opportunities (measured using the six-month index of leading indicators) play a substantial role in new issue decisions between equity and debt. Moreover, several studies indicate that corporate entities are more likely to issue long-term debt when business conditions are favorable (e.g., Marsh (1982), Bikhchandani, Hirshleifer and Welch (1998), MacKay and Phillips (2002), and Welch (2002)).

${ }^{20}$ Although the parameter estimates are not reported below, model specifications were tested that included a leading indicator (the BAA interest spread) and a coincident indicator (industrial production) in addition to a lagging indicator of business conditions (the unemployment rate). These additional business condition variables did not significantly influence issuance decisions.
} 
contemporaneous stock market excess returns $(X R) .{ }^{21,22,23}$ Third, bond market stress may make it difficult for some firms to issue debt. During periods when liquidity is at a premium, for example, both better known firms and larger issues are much more prominent in the primary debt market (Harrison (2001)). ${ }^{24}$ Because bond price volatility, regardless of whether it is driven by liquidity shocks or credit-quality shocks, tends to increase underwriting costs in a nonuniform manner across firms, some firms may find it too costly to enter the public debt market when such volatility is relatively high. As a general measure for bond market stress, we use an implied stock volatility measure that is based on real-time S\&P 100 (OEX) index option bid/ask quotes, which is supplied by the Chicago Board Options Exchange $(M K T V O L) .{ }^{25}$ It is expected that bond issuance activities would be negatively correlated with MKTVOL.

In addition, the costs and benefits of external finance are likely to vary across firms. For example, becoming a known "name” is said to lower issuance costs and to increase market demand and liquidity for an issuer's debt. ${ }^{26}$ Because frequent issuers are likely to have issued subordinated debt more than once during an annual period, an indicator variable that equals one when the banking organization has issued subordinated debt in the previous period (ISSUE $E_{i, t-1}$ ) is included in the issuance decision model to proxy for subordinated debt market name recognition. ${ }^{27}$

Because information is costly to analyze, major buyers of subordinated debt typically

\footnotetext{
${ }^{21}$ Lags in the investment process (owing to delivery, planning, and construction lags) and time-varying risk premia can cause actual investment to be negatively correlated with current returns (Lamont (2000, p. 2720)).

${ }^{22}$ The influence of overall stock market excess returns on debt issuance activities may be weak. For example, Welch (2002) has argued that the observed capital structure of U.S. firms is explained well by a firm's own past capital structure and by its stock price appreciation.
}

${ }^{23}$ For the contemporaneous stock market excess return, the quarterly average of daily excess stock returns (calculated as the difference between the daily value-weighted return on NYSE, Amex, and Nasdaq stocks and the off-the-run one month Treasury return) was used.

${ }^{24}$ Harrison (2001) argues that a severe liquidity shock (e.g., after the Russian default in 1998:Q3) is in some ways as bad for the corporate bond market as a severe credit-quality shock (e.g., during 2000-2001). With both these types of shocks to the bond market, credit spreads widen, but issuance can be more strongly curtailed in the case of a liquidity shock as some firms in the high-yield sector are totally shut out of the public debt market.

${ }^{25}$ Implied stock volatility is exogenous to, but highly correlated with, bond market volatility.

${ }^{26}$ See Board of Governors of the Federal Reserve System (1999b, p. 46.)

${ }^{27}$ More explicitly, ISSUE $E_{i, t-1}$ equals one if banking organization $i$ issued subordinated debt in either quarter $t-2$, or quarter $t-3$, and zero otherwise. 
specialize so that they purchase large amounts of the debt of a small number of large firms. ${ }^{28}$ This practice tends to reduce issuance costs for larger firms. To detect this effect, the natural log of total assets, $\ln \left(\operatorname{ASSET}_{i t}\right)$, is included in the issuance model. ${ }^{29}$

The existence of tax shelter benefits for corporate debt and increased risks of bankruptcy and agency costs with increased leverage not only affect the market value of each firm, but also determine its optimal capital structure. Hence, the firm's tax rate and its leverage are important inputs for its debt issuance decisions. ${ }^{30}$ The higher the banking organization's marginal tax rate, the greater its benefit from being able to deduct the interest payments paid to subordinated debt bondholders. As a proxy for the marginal tax rate facing each banking organization, we use its foreign and domestic income taxes as a percentage of net income (AVGTAX). As the amount of debt in the capital structure increases, the present value of tax savings will cause the market value of the firm to rise. However, at some point, the increased risk of bankruptcy and agency costs resulting from increased leverage will cause the market value of the firm to be less than it would have been if the only influence were taxes. Indeed, it is possible that bankruptcy and agency costs become so large that the market value of the firm would actually decline with an increase in leverage. Thus, the capital structure of a firm at the time that an issuance decision is made is likely to determine whether bond issuance would increase its market value. To account for differences in capital structure across banking organizations, the ratio of book equity to book total assets $(K / A)$ was included in the issuance decision model. When this ratio is large, tax benefits from debt issuance are likely to outweigh the increased risk of bankruptcy and agency costs resulting from increased leverage, but this is less likely to be the case when $K / A$ is small. Therefore, the rise in bankruptcy and agency costs associated with increased leverage suggests that debt issuance activities would be positively correlated with $K / A$.

Lastly, supervisors of a banking organization could potentially pressure its management to

\footnotetext{
${ }^{28}$ See Board of Governors of the Federal Reserve System (1999b, p. 47.)

${ }^{29}$ This proxy will also detect the risk reduction typically achieved by greater diversification or liquidity effects present at larger firms. See, for example, Morgan and Stiroh (2001, p. 200). equity.

${ }^{30}$ MacKie-Mason (1990) provide evidence of substantial tax effects on the choice between issuing debt or
} 
raise regulatory capital. ${ }^{31}$ To consider whether such pressure may have led some banking organizations to issue subordinated debt, we included two indicator variables. The first, BOPEC2, equals one if the composite supervisory rating equaled 2, and zero otherwise. The second, $B O P E C 345$, equals one if the composite supervisory rating equaled 3,4 , or 5 , and zero otherwise. Banking organizations with a composite supervisory rating of 1 or 2 are considered the safest and most well-managed institutions by supervisors. But, banking organizations with composite supervisory ratings of 3,4 , or 5 have moderate to substantial deficiencies that were uncovered during the examination process. Therefore, we would expect that banking organizations with composite supervisory ratings of 3,4 , or 5 would be under some pressure to improve their total regulatory capital, which includes subordinated debt after implementation of the Basel Accord. ${ }^{32}$

The foregoing discussion suggests that banking organization i's decision to issue subordinated debt at time $t$ will likely depend on its default probability $\left(\left(N A T A_{i t}, P_{D T A}, O_{i t}\right.\right.$, $A G A P_{i t}$, and $\left.M K T L E V_{\mathrm{it}}\right)$, business and bond market conditions $\left(U E_{t}, X R_{t}\right.$, and $\left.M K T V O L_{t}\right)$, factors that determine firm-specific benefits and costs associated with debt issuance, (ISSUE ${ }_{i, t-1}, \ln (\text { ASSETS) })_{i \text {, }}$ $A V G T A X_{i t}$, and $\left.K / A_{i t}\right)$, and supervisory pressure, $\left(B O P E C 2_{i t}\right.$ and $\left.B O P E C 345_{i t}\right)$. Thus, the decision to issue subordinated debt can be represented by

$$
\begin{aligned}
& \operatorname{ISSUE}_{i t}=f\left(\left[\text { NATA }_{i t}, \text { PDTA }_{i t}, \text { OREO }_{i t}, A G A P_{i t}, M K T L E V_{i t}\right],\left[U E_{t}, X R_{t}, M K T V O L_{t}\right]\right. \text {, } \\
& \left.\left[I S S U E_{i, t-1}, \ln \left(\text { ASSET }_{i t}\right), A V G T A X_{i t}, K / A_{i t}\right],\left[B O P E C 2_{i t}, B O P E C 345_{i t}\right]\right) .
\end{aligned}
$$

where the variable $I S S U E_{i t}$ equals one if banking organization $i$ decides to issue subordinated debt in period $t$, and zero otherwise. ${ }^{33}$ It is assumed that $\mathrm{f}($.$) is linear in all of the variables. { }^{34}$ This yields

\footnotetext{
${ }^{31}$ In recent years, supervisors have placed increasing emphasis on banking organizations’ internal processes for assessing risks and for ensuring that capital and other financial resources (e.g., subordinated debt) are adequate in relation to the overall organizations’ risk profiles. See Board of Governors of the Federal Reserve System, SR letter 99-18.

${ }^{32}$ Birchler and Hancock (2004) argue that a bank’s liability structure is a direct function of signals received on the quality of projects undertaken. After a bad signal, such as a poor supervisory rating, senior debt would be issued. After a good signal, such as a good supervisory rating, both senior and subordinated debt would be issued.

${ }^{33}$ To construct the ISSUE $_{\text {it }}$ variable, Standard and Poor's CUSIP Masterfile was used to identify all subordinated debt issues by top fifty bank holding companies. Then, for each subordinated debt issue, issuance dates were assigned using Moody's, Fitch, Bloomberg, and Warga databases. ISSUE $E_{i t}$ equals one, if banking organization $i$ issued subordinated debt in either quarter $t$ or quarter $t-1$, and equals zero, otherwise. Two quarter issuance intervals are appropriate because U.S. banking organizations rarely issue subordinated debt instruments
} 
the following specification, ${ }^{35}$

$$
\begin{aligned}
\text { ISSUE }_{i t}= & \beta_{0}+\beta_{1} \text { NATA }_{i t}+\beta_{2} P D T A_{i t}+\beta_{3} \text { OREO }_{i t}+\beta_{4} A G A P_{i t}+\beta_{5} M K T L E V_{i t} \\
& +\beta_{6} U E_{t}+\beta_{7} X R_{t}+\beta_{8} \text { MKTVOL }_{t}+\beta_{9} I_{\text {ISUE }}+\beta_{i t-1}+\beta_{10} \ln \left(A S S E T_{i t}\right) \\
& +\beta_{11} A V G T A X_{i t}+\beta_{12} \text { KIA }_{i t} \beta_{13} \text { BOPEC }_{i t}+\beta_{14} B O P E C 345_{i t}+\varepsilon_{i t}
\end{aligned}
$$

where the expected signs of parameters for business conditions (UE, XR, and MKTVOL) are negative; expected signs of the parameters for banking-organization-specific factors (ISSUE $E_{t-1}$, ln (ASSETS), AVGTAX, and K/A) are positive; and, expected signs of parameters for supervisory pressure (BOPEC2 and BOPEC345) are positive.

To estimate equation (2), we use standard latent variable techniques and treat the decision to issue as a continuous unobserved variable representing the probability that a banking organization issues subordinated debt. These techniques imply,

$$
\begin{aligned}
\operatorname{Prob}\left(\text { ISSUE }_{i t}=1\right)= & \Phi\left[\beta_{0}+\beta_{1} \text { NATA }_{i t}+\beta_{2} \text { PDTA }_{i t}+\beta_{3} \text { OREO }_{i t}+\beta_{4} A G A P_{i t}+\beta_{5} M_{\text {MKTLEV }}\right. \\
& +\beta_{6} U E_{t}+\beta_{7} X R_{t}+\beta_{8} \text { MKTVOL }_{t}+\beta_{9} \text { ISSUE }_{i, t-1}+\beta_{10} \ln \left(A S S E T_{i t}\right) \\
& \left.+\beta_{11} \text { AVGTAX }_{i t}+\beta_{12} \text { KIA }_{i t} \beta_{13} \text { BOPEC }_{i t}+\beta_{14} B O P E C 345_{i t}\right]
\end{aligned}
$$

and

$$
\operatorname{Prob}\left(\operatorname{ISSUE}_{i t}=0\right)=\left[1-\operatorname{Prob}\left(\operatorname{ISSUE}_{i t}=1\right)\right] .
$$

where $\Phi$ is the standard normal cumulative distribution function. This probit model was estimated

more frequently than twice per year (Board of Governors of the Federal Reserve System (1999b, p.46)).

${ }^{34}$ For continuous right hand side variables, the average value for a two quarter interval is used, and for binary right hand side variables, each variable is calculated over the relevant two quarter interval. The left hand side variable is set equal to one if the bank issues in a two quarter period and zero otherwise. To enhance the exogeneity of the right hand side variables, explanatory variables are lagged by one quarter.

${ }^{35}$ Based on Flannery and Sorescu (1996) we also considered a more general specification in which all of the accounting risk measures, except MKTLEV, were interacted with MKTLEV and MKTLEV ${ }^{2}$. The empirical results from this more general specification were consistent with those of the linear specification described in the text with similar conclusions about market discipline. 
using quarterly data for top fifty U.S. bank holding companies ${ }^{36}$ for three regulatory regimes: (1) the de facto TBTF” (1985-1987) regime, (2) the purchase and assumption (1988-1992) regime, and, (3) a post-FDICIA (1993-2002) regime.

In our empirical analysis, to infer the extent to which relatively risky banking organizations were deterred from issuing subordinated debt, we use joint tests of parameter estimates (i.e., Wald tests) for the traditional risk proxies (i.e., NATA, PDTA, OREO, AGAP, and MKTLEV). And, we sign the total effect of these risk proxies by summing their "normalized" marginal effects. The normalization procedure weights each marginal effect by the corresponding sample standard deviation of the risk variable. This procedure is akin to looking at the effect of a one standard deviation positive shock to all of the individual risk proxies. ${ }^{37}$

\section{SAMPLE SELECTION MODELS FOR ESTIMATING DIFFERENCES IN THE RISK-SENSITIVITY OF ISSUANCE SPREADS ACROSS DEPOSIT INSURANCE REGIMES}

As indicated in Section II, inferences about market discipline not only require knowledge about the risk-sensitivity of funding manager issuance decisions, but also knowledge about the sensitivity of subordinated debt investors to bank-specific risks. To estimate the sensitivity of banking organization subordinated debt spreads in each deposit insurance regime, we employ the Covitz, Hancock, and Kwast (2004) sample selection model. ${ }^{38,39}$

\footnotetext{
${ }^{36}$ In each quarter, the top 50 bank holding companies (BHCs) were defined as those organizations that were among the largest 50 when such organizations are ranked by asset size using holding company "Y Reports" submitted to the Federal Reserve. Thus, the top 50 BHCs can be different in each quarter. Most, but not all, top 50 BHCs have some publicly issued subordinated debt outstanding. reasonable.

${ }^{37}$ Given that the variables are highly correlated with one another, shocking them all in the same direction is

${ }^{38}$ At the time of issue, each subordinated debt instrument is most likely to be "on-the-run," rather than "offthe-run.” By considering risk-sensitivity of issuance spreads, rather than the risk-sensitivity of secondary spreads, we minimize the potentially important effects of liquidity differences on bond spreads. See Hancock and Kwast (2001).

${ }^{39}$ Consistent estimates of the sample selection model are obtained using Heckman's two-stage method, which was presented in Heckman (1974). This method involves estimating the issuance decision equation (2) with probit as described above, and then using the inverse Mills ratio function of the probit residuals as an extra variable in a regression for the observed issuance spreads. Since the conventionally estimated standard errors and associated t-statistics would not be consistent estimates for the regression for observed issuance spreads, we compute heteroskedastic-consistent standard errors and report the heteroskedastically consistent t-statistics below.
} 
Issuance spreads are posited to depend on the issuing banking organization's expected default probability, its size, its frequency of coming to the market, on systematic risks, and on the characteristics of the instrument that is issued. As with the issuance decision model, the expected default probability of banking organization $i$ is measured using several risk proxies: the ratio of nonaccruing loans to total assets $\left(N A T A_{i t}\right)$, the ratio of accruing loans past due 90 days or more to total assets $\left(P D T A_{i t}\right)$, the ratio of other real estate owned to total assets $\left(O R E O_{i t}\right)$, the absolute value of the difference between assets and liabilities maturing or repricing within one year as a proportion of equity value ( $A G A P_{i t}$ ), and the ratio of total book liabilities to the sum of the market value of common stock and the book value of preferred stock $\left(M A R K E T L E V_{i t}\right)$. Bank size is again measured by $\ln \left(A S S E T_{i t}\right)$ and the frequency of issuance is proxied by $\operatorname{ISSUE}_{i, t-1}$.

Investors may require a risk premium to compensate for systematic, rather than diversifiable, risk. ${ }^{40}$ Several researchers have demonstrated that corporate bond returns vary systematically with the same factors (e.g., excess stock returns) that are commonly accepted as explaining risk premiums for common stocks. ${ }^{41}$ Moreover, time-series models for secondary market subordinated debt spreads for large U.S. banking organizations suggest that such spreads are correlated with excess stock returns. ${ }^{42}$ Hence, a quarterly excess stock return constructed from the Center for Research in Security Prices' daily value-weighted return on NYSE, Amex, and Nasdaq stocks and daily onemonth Treasury bill rates, $X R_{t}$, is included in our observed issuance spread model.

Table 1 presents instrument characteristics (e.g., imbedded call options, maturity lengths, and coupon frequency) for the subordinated notes and debentures with issuance amounts in excess of \$75 million dollars that were issued by top 50 bank holding companies during the 1985-2002 period. ${ }^{43}$ Fixed-rate, non-callable, semi-annual coupon, long-term (10 to 20 year) bonds were the

\footnotetext{
${ }^{40}$ Elton, Gruber, Agrawal and Mann (2001) argue that corporate bond spreads could move systematically with other assets in the market because (1) expected default losses could be correlated with equity prices (i.e., default losses could decline with a rise in stock prices and default losses could increase with a fall in stock prices); and, (2) the compensation for risk required in capital markets could change over time.

${ }^{41}$ See Fama and French (1993) and Elton, Gruber, Agrawal, and Mann (2000).

${ }^{42}$ See Hancock and Kwast (2001).

${ }^{43}$ Subordinated notes and debentures with issuance amounts less than $\$ 75$ million are generally included in medium term note programs. Such issues are typically targeted toward specific retail investors and their issuance spreads include hefty liquidity premiums. Consequently, subordinated instruments with issuance amounts less than
} 
Table 1:

Characteristics of Subordinated Debt Instruments Issued by Large US Banking Organizations ${ }^{1}$

Annual Data, 1985-2002

\begin{tabular}{|c|c|c|c|c|c|c|c|c|c|c|c|c|c|c|c|c|c|c|}
\hline & \multicolumn{8}{|c|}{ Pre-FDICIA Period } & \multicolumn{10}{|c|}{ Post-FDICIA Period } \\
\hline & 1985 & 1986 & 1987 & 1988 & 1989 & 1990 & 1991 & 1992 & 1993 & 1994 & 1995 & 1996 & 1997 & 1998 & 1999 & 2000 & 2001 & 2002 \\
\hline \multicolumn{19}{|l|}{ Maturity } \\
\hline Less than 10 years & $0.00 \%$ & $0.00 \%$ & $16.67 \%$ & $0.00 \%$ & $22.22 \%$ & $10.00 \%$ & $46.67 \%$ & $34.48 \%$ & $20.00 \%$ & $25.00 \%$ & $41.46 \%$ & $28.57 \%$ & $7.69 \%$ & $15.00 \%$ & $30.00 \%$ & $33.33 \%$ & $35.71 \%$ & $0.00 \%$ \\
\hline $10-20$ years & $66.67 \%$ & $50.00 \%$ & $79.17 \%$ & $100.00 \%$ & $66.67 \%$ & $80.00 \%$ & $46.67 \%$ & $65.52 \%$ & $77.78 \%$ & $71.43 \%$ & $41.46 \%$ & $60.00 \%$ & $57.69 \%$ & $45.00 \%$ & $60.00 \%$ & $66.67 \%$ & $35.71 \%$ & $85.71 \%$ \\
\hline Greater than 20 years & $33.33 \%$ & $50.00 \%$ & $4.17 \%$ & $0.00 \%$ & $11.11 \%$ & $10.00 \%$ & $6.67 \%$ & $0.00 \%$ & $2.22 \%$ & $3.57 \%$ & $17.07 \%$ & $11.43 \%$ & $34.62 \%$ & $40.00 \%$ & $10.00 \%$ & $0.00 \%$ & $28.57 \%$ & $14.29 \%$ \\
\hline \multicolumn{19}{|l|}{ Call Option } \\
\hline Yes & $33.33 \%$ & $100.00 \%$ & $12.50 \%$ & $25.00 \%$ & $11.11 \%$ & $0.00 \%$ & $0.00 \%$ & $0.00 \%$ & $0.00 \%$ & $32.14 \%$ & $31.71 \%$ & $5.71 \%$ & $11.54 \%$ & $20.00 \%$ & $10.00 \%$ & $16.67 \%$ & $57.14 \%$ & $14.29 \%$ \\
\hline No & $66.67 \%$ & $0.00 \%$ & $87.50 \%$ & $75.00 \%$ & $88.89 \%$ & $100.00 \%$ & $100.00 \%$ & $100.00 \%$ & $100.00 \%$ & $67.86 \%$ & $68.29 \%$ & $94.29 \%$ & $88.46 \%$ & $80.00 \%$ & $90.00 \%$ & $83.33 \%$ & $42.86 \%$ & $85.71 \%$ \\
\hline \multicolumn{19}{|l|}{ Coupon Frequency } \\
\hline Monthly & $0.00 \%$ & $0.00 \%$ & $0.00 \%$ & $0.00 \%$ & $0.00 \%$ & $0.00 \%$ & $0.00 \%$ & $0.00 \%$ & $0.00 \%$ & $0.00 \%$ & $2.44 \%$ & $5.71 \%$ & $3.85 \%$ & $0.00 \%$ & $0.00 \%$ & $0.00 \%$ & $14.29 \%$ & $0.00 \%$ \\
\hline Semi-Annual & $100.00 \%$ & $100.00 \%$ & $100.00 \%$ & $100.00 \%$ & $100.00 \%$ & $100.00 \%$ & $96.67 \%$ & $100.00 \%$ & $95.56 \%$ & $100.00 \%$ & $97.56 \%$ & $94.29 \%$ & $73.08 \%$ & $85.00 \%$ & $100.00 \%$ & $100.00 \%$ & $85.71 \%$ & $85.71 \%$ \\
\hline Quarterly & $0.00 \%$ & $0.00 \%$ & $0.00 \%$ & $0.00 \%$ & $0.00 \%$ & $0.00 \%$ & $0.00 \%$ & $0.00 \%$ & $4.44 \%$ & $0.00 \%$ & $0.00 \%$ & $0.00 \%$ & $0.00 \%$ & $0.00 \%$ & $0.00 \%$ & $0.00 \%$ & $0.00 \%$ & $14.29 \%$ \\
\hline Zero Coupon & $0.00 \%$ & $0.00 \%$ & $0.00 \%$ & $0.00 \%$ & $0.00 \%$ & $0.00 \%$ & $3.33 \%$ & $0.00 \%$ & $0.00 \%$ & $0.00 \%$ & $0.00 \%$ & $0.00 \%$ & $23.08 \%$ & $15.00 \%$ & $0.00 \%$ & $0.00 \%$ & $0.00 \%$ & $0.00 \%$ \\
\hline \multicolumn{19}{|l|}{$\begin{array}{l}\text { Amount Issued } \\
\text { (in millions of dollars) }\end{array}$} \\
\hline Maximum & 150.00 & 250.00 & 300.00 & 300.00 & 400.00 & 200.00 & 750.00 & 500.00 & 600.00 & 300.00 & 443.40 & 500.00 & 800.00 & 601.50 & 1000.00 & 1900.00 & 3000.00 & 700.00 \\
\hline Minimum & 150.00 & 150.00 & 75.00 & 150.00 & 100.00 & 100.00 & 100.00 & 100.00 & 75.00 & 100.00 & 99.80 & 75.00 & 85.00 & 100.00 & 173.60 & 75.00 & 76.03 & 225.00 \\
\hline Mean & 150.00 & 200.00 & 188.54 & 187.50 & 180.56 & 138.70 & 174.00 & 192.79 & 205.00 & 188.36 & 193.22 & 244.87 & 289.13 & 284.34 & 456.95 & 679.17 & 458.02 & 403.57 \\
\hline Median & 150.00 & 200.00 & 200.00 & 150.00 & 150.00 & 118.50 & 137.50 & 200.00 & 200.00 & 150.00 & 150.00 & 247.90 & 250.00 & 250.00 & 374.30 & 400.00 & 149.61 & 300.00 \\
\hline TOTAL & 450.00 & 800.00 & 4525.00 & 750.00 & 3250.00 & 1387.00 & 5220.00 & 11182.00 & 9225.00 & 5274.20 & 7921.90 & 8570.50 & 7517.30 & 5686.68 & 4569.50 & 4075.00 & 6412.24 & 2825.00 \\
\hline Floating Rate & $0.00 \%$ & $0.00 \%$ & $8.33 \%$ & $0.00 \%$ & $11.11 \%$ & $0.00 \%$ & $0.00 \%$ & $0.00 \%$ & $4.44 \%$ & $0.00 \%$ & $0.00 \%$ & $2.86 \%$ & $0.00 \%$ & $15.00 \%$ & $0.00 \%$ & $0.00 \%$ & $0.00 \%$ & $0.00 \%$ \\
\hline $\begin{array}{l}\text { Total Number Issued } \\
\text { per Annum }\end{array}$ & 3 & 4 & 24 & 4 & 18 & 10 & 30 & 58 & 45 & 28 & 41 & 35 & 26 & 20 & 10 & 6 & 14 & 7 \\
\hline
\end{tabular}

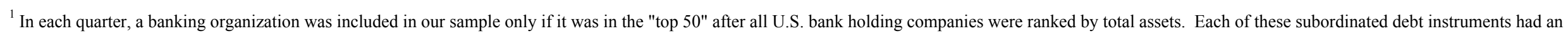
issuance size of at least $\$ 75$ million. 
most commonly issued instruments during the sample period. By and large, issues of the 20 largest bank holding companies tended to be more standardized than were issues of smaller bank holding companies. $^{44}$ And, larger holding companies were more likely to issue subordinated debt with a larger issue size. ${ }^{45}$

In principle, the value of a call option is always non-negative. This means that the "raw" calculated subordinated debt spread overestimates the default risk premium. ${ }^{46}$ An indicator variable, $C A L L_{b i}$, that equals one when bond $b$ issued by banking organization $i$ at time $t$ has a call option, and that equals zero otherwise, is included in the regression equation for observed issuance spreads. Since call options are always non-negative, it is expected that the sign on $C A L L$ would be positive. ${ }^{47}$ The percentage of new subordinated debt issues that are callable varies considerably across time for top 50 banking organizations (Table 1).

In addition, it may be the case that bonds with non-standard maturities are less liquid than are bonds with standard maturities. ${ }^{48}$ If true, then bonds with non-standard maturities would have larger spreads, ceteris paribus. To capture non-standard maturity effects on spreads, an indicator variable for bonds issued with a maturity less than 10 years, MATLT10 ${ }_{b i t}$, and an indicator variable for bonds issued with a maturity greater than 20 years, MATGT20 $0_{b i t}$ was included in the issuance

\$75 million are not included in the analysis of issuance spreads provided below.

${ }^{44}$ See Board of Governors of the Federal Reserve System and U.S. Department of the Treasury (2000, pp. 9-13).

${ }^{45}$ During the decade of the 1990s, the average size of a debt issue for the 20 largest bank holding companies more than doubled. Over the same period, the average size of a debt issue for the next 30 largest bank holding companies fluctuated around $\$ 200$ million, despite the fact that the largest issue in some years was made by a holding company in that group.

${ }^{46}$ The value of a bond's call option increases with its maturity and the volatility of market interest rates, and decreases with the required call premium. See Avery, Belton, and Goldberg (1988), Gorton and Santomero (1990), and Flannery and Sorescu (1996) for methods used to compute option-adjusted spreads. Alternatively, Boardman and McEnally (1981) used a net present value calculation for deciding when to call an issue in their analysis of the factors that affect seasoned corporate bond prices.

${ }^{47} \mathrm{~A}$ negative or zero coefficient on the call option indicator variable would imply that debt holders did not value the call option appropriately.

${ }^{48}$ Non-standard maturity instruments may be issued by banking organizations to match the duration of their liabilities with the duration of their assets, or these instruments may be issued when an organization wants to attract funds from small retail investors. 
spread regression. ${ }^{49}$ Each of these indicator variables equals one for the specified maturity range, and zero otherwise. Since non-standard maturities are expected to raise spreads, it is expected that the sign on these maturity indicator variables would be positive.

It also seems reasonable that coupon frequency could affect the types of investors willing to purchase an issue. Presumably, higher coupon frequency (e.g., monthly coupon payments) would attract smaller "retail” investors, and the resulting higher demand would lower the issuance spread. To capture this potential effect on the subordinated debt spread, we include two indicator variables, COUPON12 $2_{b i t}$ and COUPON2 $2_{b i t}$, that equal one when the coupon frequency is monthly and semiannually, respectively, and that equal zero otherwise. Our reasoning suggests that the coefficients on the monthly coupon frequency indicator will be negative. Interestingly, monthly coupons are only observed on subordinated notes and debentures issued in the post-FDICIA period (Table 1).

It is expected that issuance spreads are likely to be negatively correlated with issuance size $\left(I S S U E S I Z E_{b i t}\right)$ for at least two reasons. First, larger issues may command higher prices (i.e., lower spreads) because smaller issues tend to be less liquid in the secondary market. ${ }^{50,51}$ For this reason, smaller issues are more difficult and expensive to sell to institutional investors. ${ }^{52}$ Second, given a banking organization's total assets and its equity capital ratio, a larger bond issue (i.e., one with a greater issuance size) could reflect an organization having a larger proportion of subordinated bonds relative to deposits. The higher preference given to depositors than to subordinated debt holders in bankruptcy implies that expected recovery rates on subordinated debt are higher when there is more

\footnotetext{
${ }^{49}$ Maturities and other instrument characteristics for each subordinated bond were identified using Moody’s Default Risk Service data base, Fixed Investment Securities Database, Warga and Bloomberg data bases as well as monthly issues of Mergent Bond Record over the January 1984-December 2002 period, inclusive.

${ }^{50}$ Smaller issues tend to be less liquid because they tend to rapidly get absorbed into investor portfolios. Hancock and Kwast (2001) present histograms of weekly subordinated debt spread discrepancies between Bloomberg and Interactive Data Corporation pricing data sources over the January 1997 to October 1999 period for bonds stratified by issuance size. The tightest distribution of spread discrepancies is for bonds with issuance sizes greater than $\$ 300$ million. The next tightest distribution was for bonds with issuance sizes between $\$ 100$ million and $\$ 300$ million. And, the widest distribution was for bonds with issuance sizes less than $\$ 100$ million. The decreased dispersion in spread discrepancies for larger issues suggests that there may be a positive correlation between the flow of trade in a particular bond and its amount outstanding at issuance.

${ }^{51}$ Supporting evidence for this liquidity effect is found in Morgan and Stiroh (2000): They report that issuance spreads were significantly smaller for larger issues in their study.

${ }^{52}$ See Board of Governors of the Federal Reserve System (1999b, p. 46.)
} 
subordinated debt relative to deposits, ceteris paribus. Higher expected recovery rates would imply lower issuance spreads. ${ }^{53}$

The regression estimated for observed issuance spreads over Treasury securities with comparable maturities in each deposit insurance regime is: ${ }^{54,} 55$

$$
\begin{aligned}
\text { SPREAD }_{b i t}=\gamma_{0} & +\gamma_{1} \text { NATA }_{i t}+\gamma_{2} \text { PDTA }_{i t}+\gamma_{3} \text { OREO }_{i t}+\gamma_{4} \text { AGAP }_{i t}+\gamma_{5} \text { MKTLEV }_{i t} \\
& +\gamma_{6} \text { ISSUE }_{i, t-1}+\gamma_{7} \ln \left(\text { ASSET }_{i t}\right)+\gamma_{8} \text { XR }_{t} \\
& +\gamma_{9} \text { CALL }_{b i t}+\gamma_{10} \text { MATLT10 }_{b i t}+\gamma_{11} \text { MATGT20 }_{b i t} \\
& +\gamma_{12} \text { COUPON12 }_{b i t}+\gamma_{13} \text { COUPON }_{b i t} \\
& +\gamma_{14} \text { ISSUESIZE }_{b i t}+\gamma_{15} \text { MILLSRATIO }_{b i t}+\mu_{b i t}
\end{aligned}
$$

Each observed SPREAD ${ }_{b i t}$ was calculated from observed trading prices using derived yields on each bond calculated by the Newton-Ralphson iterative method and an interpolated Treasury yield of the same maturity. ${ }^{56}$

Because of the relationships between the banking organization-specific risk proxies, the variances of each individual risk proxy parameter estimate can be misleadingly large. Therefore, we consider the joint effects of the risk proxies (i.e., NATA, PDTA, OREO, AGAP, and MKTLEV) using Wald tests. ${ }^{57}$ To ascertain the sign of the joint risk effect, information is presented on (1) the distribution of the joint risk effects calculated using the parameter estimates and banking

\footnotetext{
${ }^{53}$ See Pennacchi (2001).

${ }^{54}$ Note that there are extra identifying variables in the issuance decision model: $U E, B O P E C 2$, and BOPEC345.

${ }^{55}$ A nonlinear specification for the risk variables, similar to that estimated by Flannery and Sorescu (1996), was also estimated. This specification yielded results that were qualitatively similar to the more straightforward to interpret linear specification that is reported below.

${ }^{56}$ Issuance prices were obtained from the Bloomberg "generic" bond pricing series, which is constructed using the consensus method that averages observed trading prices after dropping the highest and lowest observations. For the consensus method, a minimum of three observations is required, after dropping the highest and lowest observations, for a price to be valid, otherwise a missing value is entered for the trading price. Valid trading prices were obtained on all issuance dates (i.e., no "matrix prices" were used). The term structure of Treasury interest rates was identified on each trading price issuance date by using a smoothing spline of the forward rate curve that incorporates a "roughness" penalty determined by generalized cross validation. This splining technique is described in Fisher, Nychka, and Zervos (1994).
}

${ }^{57}$ This approach was also used in Flannery and Sorescu (1996, p. 1361). 
organization-specific values for the risk proxies, (2) the sign and significance of a risk aggregate that is constructed using principal component techniques, ${ }^{58}$ and (3) the sum of the "normalized" risk effects. $^{59}$

If conjectural government guarantees made subordinated debt investors completely insensitive to bank risks during the de facto TBTF period, for example, then the joint risk effect contained in issuance spreads would not be statistically significant. If, however, subordinated bond market investors were sensitive to bank-specific risks during that period - or during subsequent periods - then the joint risk effect would be positive and statistically significant, regardless of whether such investors were risk neutral or punitive.

To identify whether deposit insurance reforms influenced the risk-sensitivity of banking organization debt spreads, we estimated sample selection models using data from two adjoining deposit insurance regimes. In these regime effect models, the list of explanatory variables not only included the original set of explanatory variables, but also included that set interacted with a deposit insurance regime indicator variable. The deposit insurance regime indicator variable, $I_{t}$, is set equal to zero in the first regime and to equal one in the subsequent regime. The regression estimated for the observed subordinated debt spreads over comparable maturity Treasury securities using data from two adjoining deposit insurance regimes is:

$$
\begin{aligned}
& S P R E A D_{b i t}=\gamma_{0}+\gamma_{1 p} N A T A_{i t}+\gamma_{2 p} P D T A_{i t}+\gamma_{3 p} O R E O_{i t}+\gamma_{4 p} A G A P_{i t}+\gamma_{5 p} M K T L E V_{i t} \\
& +\gamma_{1 s} N A T A_{i t} I_{t}+\gamma_{2 s} \text { PDTA } i t I_{t}+\gamma_{3 s} \text { OREO } i t I_{t}+\gamma_{4 s} A G A P_{i t} I_{t}+\gamma_{5 s} \text { MKTLEV } V_{i t} I_{t} \\
& +\gamma_{6 p} I S S U E_{i, t-1}+\gamma_{7 p} \ln \left(A S S E T_{i t}\right)+\gamma_{8 p} X R_{t} \\
& +\gamma_{6 s} I S S U E_{i, t-1} \cdot I_{t}+\gamma_{7 s} \ln \left(A S S E T_{i t}\right) \cdot I_{t}+\gamma_{8 s} X R_{t} \cdot I_{t}
\end{aligned}
$$

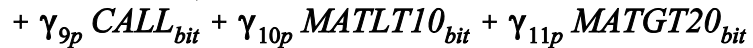

$$
\begin{aligned}
& +\gamma_{9 s} C_{\text {CALL }} \text { bit } I_{t}+\gamma_{10 s} \text { MATLT10 }_{b i t} \cdot I_{t}+\gamma_{11 s} \text { MATGT20 }_{b i t} I_{t} \\
& +\gamma_{12 p} \text { COUPON12 }_{b i t}+\gamma_{13 p} \text { COUPON2 }_{b i t}+\gamma_{14 p} \text { ISSUESIZE }_{b i t} \\
& +\gamma_{12 s} \text { COUPON12 } 2_{b i t} \cdot I_{t}+\gamma_{13 s} \text { COUPON2 }_{b i t} \cdot I_{t}+\gamma_{14 s} \text { ISSUESIZE }_{b i t} \cdot I_{t} \\
& +\gamma_{15 p} M_{I L L S R A T I O}{ }_{b i t}+\gamma_{15 s} M_{I L L S R A T I O}{ }_{b i t} I_{t}+\mu_{b i t} \text {. }
\end{aligned}
$$

\footnotetext{
${ }^{58}$ Each principal component is a linear combination of the original risk proxies, with coefficients equal to eigenvectors of the covariance matrix. We used the first principal component, which has the largest variance of any unit-length linear combination of the observed risk proxies.

${ }^{59}$ The normalization involves multiplying a risk proxy's marginal effect by the sample standard deviation of that proxy. Summing these normalized effects across all risk proxies is akin to looking at the effect of a one standard deviation positive shock to all individual risk proxies. Given that the risk proxies are highly correlated, shocking them all in the same direction is reasonable. Since the parameter estimates are not all positive, it is noted that this procedure does not provide an upper bound on the joint risk effect.
} 
where the $p$ subscript indicates that the parameter estimate pertains to the period prior to the deposit insurance regime change and the $s$ subscript indicates that the parameter estimate is for an explanatory variable interacted with the deposit insurance regime indicator variable. This specification allows not only for deposit insurance reforms to influence the risk-sensitivity of debt spreads, but also allows the influence of other banking organization-specific factors, business conditions, and instrument characteristics on spreads to evolve over time. Each parameter estimate with an $s$ subscript is significant only when that specific variable has a statistically different (i.e., an additional) effect on issuance spreads during the subsequent deposit insurance regime. In addition, a Wald test is used to consider whether the additional effects for the traditional risk proxies jointly equal zero (i.e., whether there was no change in the risk-sensitivity of issuance spreads across adjoining deposit insurance regimes).

\section{EMPIRICAL RESUlts \\ ISSUANCE DECISIONS}

The issuance decision and issuance spread models were estimated using quarterly data for each of the three regulatory regimes: de facto TBTF (1985-1987), purchase and assumption (19881992), and post-FDICIA (1993-2002). Table 2 presents mean probability derivatives for the issuance decision probit model. ${ }^{60}$ In Table 2, one asterisk is placed next to a mean probability derivative when the corresponding parameter estimate in the probit model (equation 3) is significant at the 10 percent confidence level. And, two asterisks are placed next to a mean probability derivative when the corresponding parameter estimate is significant at the 10 percent level and it is of the expected sign.

Individually, the traditional risk proxies were rarely significant in the three deposit insurance regimes under consideration. In the de facto TBTF regime, two risk proxies are significant at the 10 percent level of confidence - NATA and AGAP) - but only AGAP is of the expected (negative)

\footnotetext{
${ }^{60}$ Analytic first and second derivatives were used to obtain maximum likelihood estimates for the probit via the Newton-Raphson algorithm. The numerical implementation of this approach evaluates the normal density and the cumulative normal distribution functions with the later function being computed from an asymptotic expansion, since it has no closed form. Each of the mean probability derivatives incorporates the ratio of the density to the distribution function (also known as the Mills ratio). Standard errors for the parameter estimates are computed from the analytic second derivatives.
} 
Table 2: Mean Probability Derivatives for the Issuance Decision Model for Subordinated Debt (Large U.S. Banking Organizations, Alternative Deposit Insurance Regulatory Regimes)

\begin{tabular}{|c|c|c|c|}
\hline \multirow{3}{*}{ Explanatory Variables } & \multicolumn{3}{|c|}{ Dependent Variable/ Deposit Insurance Regime } \\
\hline & \multicolumn{3}{|c|}{ Decision to Issue } \\
\hline & $\begin{array}{l}\text { De Facto TBTF } \\
85: \mathrm{Q} 1-87: \mathrm{Q} 4 \\
\end{array}$ & $\begin{array}{c}\text { Purchase \& Assumption } \\
\text { 88:Q1-92:Q4 } \\
\end{array}$ & $\begin{array}{c}\text { Post-FDICIA Sample } \\
\text { 93:Q1-02:Q4 } \\
\end{array}$ \\
\hline $\begin{array}{l}\text { Accounting-and Market-based } \\
\text { Risk Measures }\end{array}$ & & & \\
\hline $\begin{array}{l}\text { The ratio of non-accruing loans to } \\
\text { total assets (NATA) }\end{array}$ & $4.801 *$ & $-2.665 * *$ & -3.489 \\
\hline $\begin{array}{l}\text { The ratio of accruing loans past due } \\
90 \text { days of more to total assets } \\
\text { (PDTA) }\end{array}$ & -11.776 & -13.205 & 2.184 \\
\hline $\begin{array}{l}\text { The ratio of other real estate owned } \\
\text { to total assets (OREO) }\end{array}$ & -1.160 & 1.709 & 8.181 \\
\hline $\begin{array}{l}\text { The absolute value of the difference } \\
\text { between assets and liabilities } \\
\text { maturing or repricing within one } \\
\text { year as a proportion of equity value } \\
\text { (AGAP) }\end{array}$ & $-0.012 * *$ & 0.0004 & -0.007 \\
\hline $\begin{array}{l}\text { The ratio of total book liabilities to } \\
\text { the sum of the market value of } \\
\text { common stock and the book value } \\
\text { of preferred stock (MKTLEV) }\end{array}$ & 0.003 & -0.004 & 0.007 \\
\hline $\begin{array}{l}\text { Other Banking Organization- } \\
\text { Specific Factors }\end{array}$ & & & \\
\hline $\begin{array}{l}\text { The natural log of total assets } \\
(\ln (\text { ASSETS }))\end{array}$ & $0.093 * *$ & $0.135 * *$ & $0.115 * *$ \\
\hline $\begin{array}{l}\text { An indicator variable that equals } \\
\text { one if the banking organization } \\
\text { issued SND in the preceding } 6 \\
\text { month period, and zero otherwise } \\
\left(\text { ISSUE }_{-1}\right)\end{array}$ & 0.057 & $0.072 * *$ & $0.160 * *$ \\
\hline $\begin{array}{l}\text { Foreign and domestic income taxes } \\
\text { as a percentage of net income } \\
\text { (AVGTAX) }\end{array}$ & 0.00005 & 0.000008 & -0.0001 \\
\hline $\begin{array}{l}\text { The ratio of book equity to book } \\
\text { total assets (KA) }\end{array}$ & 1.701 & -1.450 & -0.448 \\
\hline
\end{tabular}

* Parameter estimates are statistically significant at the $10 \%$ level.

** Parameter estimates are statistically significant at the $10 \%$ level and have the predicted sign. 
Table 2 Continued

\begin{tabular}{|c|c|c|c|}
\hline \multirow{3}{*}{ Explanatory Variables } & \multicolumn{3}{|c|}{ Dependent Variable/ Deposit Insurance Regime } \\
\hline & \multicolumn{3}{|c|}{ Decision to Issue } \\
\hline & $\begin{array}{c}\text { De Facto TBTF } \\
\text { 85:Q1-87:Q4 } \\
\end{array}$ & $\begin{array}{c}\text { Purchase \& Assumption } \\
\text { 88:Q1-92:Q4 } \\
\end{array}$ & $\begin{array}{c}\text { Post-FDICIA Sample } \\
\text { 93:Q1-02:Q4 }\end{array}$ \\
\hline \multicolumn{4}{|l|}{$\begin{array}{l}\text { Business and Bond Market } \\
\text { Conditions }\end{array}$} \\
\hline The unemployment rate (UE) & $-0.135 * *$ & 0.026 & $0.052 *$ \\
\hline Stock Market Excess Return (XR) & -0.001 & -0.001 & $-0.003 *$ \\
\hline $\begin{array}{l}\text { The implied stock volatility } \\
\text { measure calculated from option } \\
\text { prices traded on the Chicago Board } \\
\text { Options Exchange (MKTVOL) }\end{array}$ & $-0.014 * *$ & $-0.008 * *$ & $-0.006 * *$ \\
\hline Supervisory Pressure & & & \\
\hline $\begin{array}{l}\text { An indicator variable that equals } \\
\text { one if the composite supervisory } \\
\text { rating equals } 2\left(\mathrm{BOPEC}_{2}\right)\end{array}$ & -0.053 & 0.017 & 0.007 \\
\hline $\begin{array}{l}\text { An indicator that equals one if the } \\
\text { composite supervisory rating equals } \\
3,4 \text { or } 5\left(\text { BOPEC }_{345}\right)\end{array}$ & -0.173 & -0.017 & 0.009 \\
\hline \multicolumn{4}{|l|}{ Wald Tests } \\
\hline $\begin{array}{l}\text { Wald test statistics for "risk" } \\
\text { coefficients jointly equalling zero }\end{array}$ & 8.6 & 45.3 & 76.0 \\
\hline $\begin{array}{l}\text { Critical value for the Wald Test at } \\
\text { the } 5 \text { percent confidence level }\end{array}$ & 11.1 & 11.1 & 11.1 \\
\hline Sign of Joint Risk Effect? & & & \\
\hline $\begin{array}{l}\text { The sum of the normalized } \\
\text { marginal risk effects }\end{array}$ & -0.016 & -0.066 & -0.094 \\
\hline \multicolumn{4}{|l|}{ Goodness of Fit Measures } \\
\hline $\begin{array}{l}\text { Fraction of correct predictions for } \\
\text { issuance decision }\end{array}$ & 0.88 & 0.84 & 0.85 \\
\hline R-squared & 0.24 & 0.21 & 0.31 \\
\hline Number of observations & 539 & 941 & 1933 \\
\hline $\begin{array}{l}\text { Percent that issued subordinated } \\
\text { debt }\end{array}$ & 14.47 & 18.28 & 21.83 \\
\hline
\end{tabular}

* Parameter estimates are statistically significant at the $10 \%$ level.

** Parameter estimates are statistically significant at the $10 \%$ level and have the predicted sign.

Note: Mean probability derivates are calculated using the ratio of the density to the distribution function (i.e., the inverse Mills ratio). The numerical implementation involves evaluating the normal density and cumulative normal distribution functions. Since the cumulative normal distribution function has no closed form, it is computed from an asymptotic expansion. 
sign. In the purchase and assumption regime, only NATA among the risk proxies is significant and of the expected sign. And, in the post-FDICIA regime, none of the risk proxies are significant. As indicated above, this finding is expected since the five risk proxies are related to one another. It is, therefore, important to consider joint tests for the significance of the traditional banking organization-specific risk proxies.

The middle panel of Table 2 presents the Wald test and sign for the joint effects of the risk proxies on the likelihood that a banking organization would issue subordinated debt in each deposit insurance regime. During the de facto TBTF (1985-1987) regime, the Wald statistic for the joint test for the significance of the traditional banking organization-specific risk proxies is only 8.6 against a critical value of 11.1 at the five percent confidence level. This implies that risky banks were no more or less likely to issue subordinated debt during the de facto TBTF (1985-1987) regime. In contrast, the traditional banking organization-specific risk proxies significantly affected the likelihood that large U.S. banking organizations would issue subordinated debt in the purchase and assumption (1988-1992) regime and in the post-FDICIA (1993-2002) period. Wald test statistics for the traditional risk proxy parameter estimates jointly equaling zero are 45.3 and 76.0 in these two periods, respectively. Each of these test statistics is greater than the critical value for the Wald test at a 5 percent confidence level (11.1). ${ }^{61}$ Moreover, the sum of the normalized marginal effects for the risk proxies is negative in all three deposit insurance regimes. These findings imply that the riskiest banks were less likely to issue subordinated debt in the 1988-2002 period.

Banking organization-specific factors, such as asset size (ln $\left(\right.$ ASSETS $\left.\left._{i t}\right)\right)$ and whether the banking organization had issued subordinated debt in the previous six-month period (ISSUE $\left.E_{i, t-1}\right)$, also significantly influenced funding manager decisions. Larger banking organizations and more frequent issuers were more likely to issue subordinated debt during each of the three deposit insurance regimes considered.

Overall market conditions matter when it comes to bank subordinated debt issuance decisions. In the de facto TBTF period, higher unemployment $\left(U E_{t}\right)$ significantly reduced bank subordinated debt issuance activities. And, in all three deposit insurance regimes, it was less likely

\footnotetext{
${ }^{61} \mathrm{~A}$ two-tailed test statistic is appropriate for this joint test because it is unclear whether more organizationspecific risk would increase or reduce the likelihood that a funding manager would issue subordinated debt.
} 
for a large U.S. banking organization to issue subordinated debt in periods of bond market illiquidity (i.e., when the implied volatility $\left(M K T V O L_{t}\right)$ increased).

Importantly, banking organizations with supervisory ratings in the 3 to 5 range were less likely to issue subordinated debt during the de facto TBTF period. To the extent that this risk measure proxies for "private information" held by the funding manager, this finding suggests that subordinated debt issuance activities were used to signal "good” financial prospects to the market. ${ }^{62}$ These results also suggest that supervisors were not pressuring banking organizations that were in financial distress during this period to increase the noninsured liabilities "buffer" that would absorb potential losses from their failure.

\section{ISSUANCE SPREADS}

Parameter estimates for the sample selection models estimated using data from each of the three deposit insurance regimes are presented in Table 3. One asterisk placed next to a parameter estimate in Table 3 indicates that it is significant at the 10 percent confidence level. And, two asterisks placed next to a parameter estimate in Table 3 indicate that it is both significant at the 10 percent level and is of the expected sign.

Strikingly, there are as many significantly positive traditional risk proxies in the de facto TBTF (1985-1987) period as there are in the post-FDICIA (1993-2002) period. And, almost all of the traditional risk proxies are positive and significant in the purchase and assumption period (19881992). Given these significantly positive effects, it is perhaps unsurprising that the joint risk effects are also significant and positive (middle panel, Table 3).

In the de facto TBTF (1985-1987) period, ${ }^{63}$ the Wald test statistic for the joint test for the significance of the traditional banking organization-specific risk proxies on issuance spreads is 27.4, which is well in excess of the critical value for the five percent confidence level (11.1). The distribution of the joint risk effects has a positive mean (0.689) with the vast majority of banking organizations having a fairly large positive joint effect in the distribution of the estimated risk

\footnotetext{
${ }^{62}$ See, for example, Covitz and Harrison (2003).

${ }^{63}$ It is notable that the identifying variables in the issuance decision model (UE, BOPEC2, and BOPEC345) are jointly significant for the de facto TBTF period. The Wald test statistic is 10.664 against a critical value of 7.61 for a five percent confidence level.
} 


\section{Table 3: Parameter Estimates for the Sample Selection Model for Observed Subordinated Debt Issuance Spreads}

(Large U.S. Banking Organizations, Alternative Deposit Insurance Regulatory Regimes)

\begin{tabular}{|c|c|c|c|}
\hline \multirow{3}{*}{ Explanatory Variables } & \multicolumn{3}{|c|}{ Dependent Variable / Deposit Insurance Regime } \\
\hline & \multicolumn{3}{|c|}{ Spread over Treasury Securities with Comparable Maturities } \\
\hline & $\begin{array}{l}\text { De Facto TBTF } \\
\text { 85:Q1-87:Q4 }\end{array}$ & $\begin{array}{c}\text { Purchase \& Assumption } \\
\text { 88:Q1-92:Q4 }\end{array}$ & $\begin{array}{c}\text { Post-FDICIA Sample } \\
\text { 93:Q1-02:Q4 }\end{array}$ \\
\hline \multicolumn{4}{|l|}{$\begin{array}{l}\text { Accounting- and Market- based } \\
\text { Risk Measures }\end{array}$} \\
\hline $\begin{array}{l}\text { The ratio of non-accruing loans to total assets } \\
\text { (NATA) }\end{array}$ & $\begin{array}{c}51.183 * * \\
(1.98)\end{array}$ & $\begin{array}{c}-9.384 * * \\
(-1.75)\end{array}$ & $\begin{array}{l}-3.430 \\
(-0.48)\end{array}$ \\
\hline $\begin{array}{l}\text { The ratio of accruing loans past due } 90 \text { days of } \\
\text { more to total assets (PDTA) }\end{array}$ & $\begin{array}{l}618.065 * * \\
(2.92)\end{array}$ & $\begin{array}{r}56.914 \\
(1.53)\end{array}$ & $\begin{array}{c}78.157 * * \\
(3.01)\end{array}$ \\
\hline $\begin{array}{l}\text { The ratio of other real estate owned to total assets } \\
\text { (OREO) }\end{array}$ & $\begin{array}{c}-291.452 * \\
(-2.61)\end{array}$ & $\begin{array}{l}59.531 * * \\
(4.14)\end{array}$ & $\begin{array}{l}-3.808 \\
(-0.32)\end{array}$ \\
\hline $\begin{array}{l}\text { The absolute value of the difference between assets } \\
\text { and liabilities maturing or repricing within one yea } \\
\text { as a proportion of equity value (AGAP) }\end{array}$ & $\begin{array}{l}-0.158 \\
(-1.41)\end{array}$ & $\begin{array}{c}0.007 * * \\
(1.69)\end{array}$ & $\begin{array}{l}-0.002 \\
(-0.14)\end{array}$ \\
\hline $\begin{array}{l}\text { The ratio of total book liabilities to the sum of the } \\
\text { market value of common stock and the book value } \\
\text { of preferred stock (MKTLEV) }\end{array}$ & $\begin{array}{l}-0.062 \\
(-1.58)\end{array}$ & $\begin{array}{c}0.075 * * \\
(4.79)\end{array}$ & $\begin{array}{c}0.053 * * \\
(3.57)\end{array}$ \\
\hline \multicolumn{4}{|l|}{$\begin{array}{l}\text { Banking Organization-Specific } \\
\text { Factors }\end{array}$} \\
\hline The natural log of total assets ( $\ln ($ ASSETS) & $\begin{array}{l}-2.060 * * \\
(-1.85)\end{array}$ & $\begin{array}{l}-0.210 \\
(-0.95)\end{array}$ & $\begin{array}{l}0.108 \\
(0.61)\end{array}$ \\
\hline $\begin{array}{l}\text { An indicator variable that equals one if the banking } \\
\text { organization issued SND in the preceding } 6 \text { month } \\
\text { period, and zero otherwise (ISSUE_-1) }\end{array}$ & $\begin{array}{c}-1.328 * * \\
(-1.75)\end{array}$ & $\begin{array}{l}-0.187 \\
(-1.46)\end{array}$ & $\begin{array}{l}0.023 \\
(0.09)\end{array}$ \\
\hline \multicolumn{4}{|l|}{ Business Conditions } \\
\hline Stock Market Excess Return (XR) & $\begin{array}{l}0.024 \\
(1.33)\end{array}$ & $\begin{array}{l}0.011 \\
(1.56)\end{array}$ & $\begin{array}{l}0.007 \\
(1.52)\end{array}$ \\
\hline \multicolumn{4}{|l|}{ Instrument Characteristics } \\
\hline $\begin{array}{l}\text { An indicator that equals one when an issue has a } \\
\text { call option (CALL) }\end{array}$ & $\begin{array}{l}0.359 \\
(0.58)\end{array}$ & $\begin{array}{l}0.177 \\
(1.00)\end{array}$ & $\begin{array}{c}0.211 * * \\
(3.50)\end{array}$ \\
\hline $\begin{array}{l}\text { An indicator that equals one when an issue has a } \\
\text { maturity less than ten years (MATLT10) }\end{array}$ & $\begin{array}{c}-0.826 * \\
(-1.77)\end{array}$ & $\begin{array}{c}0.163 * * \\
(1.98)\end{array}$ & $\begin{array}{c}0.149 * * \\
(3.93)\end{array}$ \\
\hline $\begin{array}{l}\text { An indicator that equals one when an issue has a } \\
\text { maturity greater than twenty years (MATGT20) }\end{array}$ & $\begin{array}{c}1.218 * * \\
(1.87)\end{array}$ & $\begin{array}{c}0.265 * * \\
(1.97)\end{array}$ & $\begin{array}{c}0.130 * * \\
(1.70)\end{array}$ \\
\hline
\end{tabular}

* Parameter estimates are statistically significant at the $10 \%$ level.

** Parameter estimates are statistically significant at the $10 \%$ level and have the predicted sign. 
Table 3 Continued

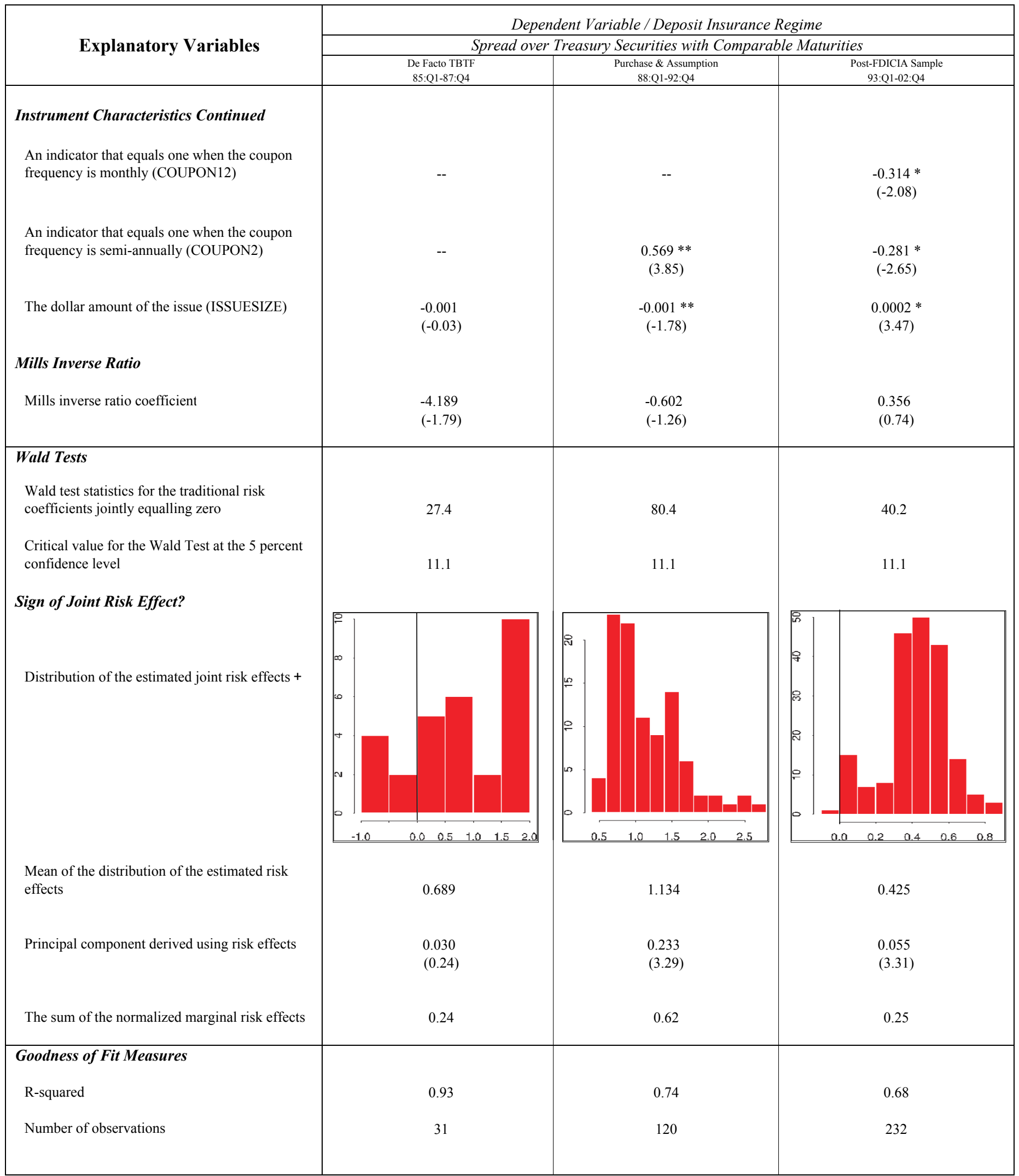

* Parameter estimates are statistically significant at the $10 \%$ level.

** Parameter estimates are statistically significant at the $10 \%$ level and have the predicted sign.

+ A vertical line appears at zero in each distribution of the estimated risk effects.

Note: All specifications include a constant term which was significant at the $5 \%$ level. Year indicator variables, which were equal to one in a specific year, and zero otherwise were also included. Observed spread regressions are heteroskedastic-consistent. T-Statistics are in parentheses. 
effects. ${ }^{64}$ And, the sum of normalized marginal risk effects equals 0.24 .

The evidence in favor of a significant and positive joint risk effect on issuance spreads is even stronger for the purchase and assumption (1988-1992) period. The Wald test statistic for the joint test for the significance of the traditional banking organization-specific risk proxies is 80.4 well above the critical value of 11.1 for the five percent confidence level. The distribution of estimated risk effects with mean equal to 1.134 only contains positive effects. The principal component derived from banking organization-specific risk proxy effects is both positive (0.233) and significant (with a t-statistic equaling 3.29). And, the sum of the normalized marginal risk effects is a positive 0.62 , which is more than twice the size of the sum of the normalized marginal risk effects during the de facto TBTF (1985-1987) period.

As was the case for the purchase and assumption (1988-1992) period, there is strong evidence of a significant and positive joint risk effect on issuance spreads for the post-FDICIA (1993-2002) period. ${ }^{65}$ The Wald test statistic for the joint test for the significance of the traditional banking organization-specific risk proxies is 40.2 , which is above the 11.1 critical value for the five percent confidence level. The distribution of the estimated risk effects contains only a few negative effects, and is highly concentrated around its mean of 0.425 . The principal component derived from banking organization-specific risk proxy effects is positive (0.055) and significant (with a t-statistic equaling 3.31). In addition, the sum of the normalized risk effects is positive at 0.25 .

Interestingly, the principal component derived for the post-FDICIA (1993-2002) period at 0.055 is about a quarter of the size of the principal component derived for the purchase and assumption (1988-1992) period at 0.233. Consistent with this finding, the sum of the normalized marginal risk effects for the post-FDICIA (1993-2002) period at 0.25 is less than half the size of the sum of the normalized marginal risk effects for the purchase and assumption (1988-1992) period at 0.62. Together, these findings suggest that there may have been a decrease in the risk sensitivity of subordinated debt spreads between the purchase and assumption period (1988-1992) and the post-

\footnotetext{
${ }^{64}$ The principal component derived from banking organization-specific risk proxy effects is positive, albeit not significant.

${ }^{65}$ The identifying variables in the issuance decision model (UE, BOPEC2, and BOPEC345) are jointly significant for the post-FDICIA period. The Wald test statistic is 9.782 against a critical value of 7.61 for a five percent confidence level..
} 
FDICIA period (1993-2002). Such a finding would be consistent with subordinated investors perceiving that prompt corrective actions by bank supervisors would likely reduce their expected losses in the event of a bank failure, despite their lower liquidation standing due to FDICIA and depositor preference rules.

Banking organization-specific factors - bank size $\left(\ln \left(\right.\right.$ ASSETS $\left._{i t}\right)$ and frequency of issuance $\left.I S S U E_{i, t-1}\right)$ - significantly reduced issuance spreads only in the de facto TBTF (1985-1987) period. More recently, such factors have become less important to subordinated investors.

The effects of instrument characteristics on issuance spreads are generally of the expected sign when they are statistically significant, but different characteristics increase or reduce spreads more in some deposit insurance regimes than others. For example, call options (CALL) significantly increased issuance spreads over comparable maturity Treasury securities only in the post-FDICIA (1993-2002) period. Instruments with non-standard maturities (MATLT10 and MATGT20) generally commanded higher spreads consistent with such bonds being less liquid than bonds with standard maturities. And, instruments with higher than normal coupon frequency (COUPON12 and COUPON2) appear to have attracted more retail investors during the post-FDICIA (1993-2002) period, since such instruments had significantly smaller spreads which presumably reflected higher demand for them. These findings imply that funding manager decisions with respect to instrument characteristics are important to consider when one compares issuance spreads across banking organizations. ${ }^{66}$

Although the parameter estimate on the inverse Mills ratio (bottom panel, Table 3) is by itself insignificant in each of the deposit insurance regimes considered, inclusion of this variable importantly affects the significance and magnitude of the other parameter estimates included in the sample selection model. ${ }^{67}$ The insignificance of the inverse Mills ratio mainly reflects that it is correlated with other variables in the model for issuance spreads.

\section{THE IMPORTANCE OF DEPOSIT INSURANCE REFORMS}

The results presented thus far strongly suggest that deposit insurance reforms have influenced the risk-sensitivity of banking organization debt spreads in the primary debt market. In

\footnotetext{
${ }^{66}$ These finding are consistent with those reported in Morgan and Stiroh (2001).

${ }^{67}$ See Covitz, Hancock and Kwast (2004).
} 
addition, it appears that the influence of other banking organization-specific factors, business conditions, and instrument characteristics on such spreads may have evolved over time.

In Table 4, two separate tests for the effects of deposit insurance regime change on banking organization subordinated issuance spreads are presented: (1) the de facto TBTF (1985-1987) period is compared to the purchase and assumption (1988-1992) period; and, (2) the purchase and assumption (1988-1992) period is compared to the post-FDICIA (1993-2002) period. The direct effects are shown in columns (1) and (3) of Table 4 and these effects correspond to the parameter estimates for the sample selection models (presented in Table 3) for the de facto TBTF and the purchase and assumption regimes, respectively. Column (2) contains the additional effects for the purchase and assumption regime that correspond to the direct effects for the de facto TBTF regime contained in column (1). Analogously, column (4) contains the additional effects for the postFDICIA regime that correspond to the direct effects for the purchase and assumption regime contained in column (3). As in previous tables, one asterisk is placed on parameter estimates that are statistically significant at the 10 percent level and two asterisks are placed on such estimates that also are of the expected sign. In the bottom panel of Table 4, Wald tests and sign tests are provided for the additional effects for the traditional risk coefficients jointly equaling zero (i.e., for no change in the risk-sensitivity of issuance spreads between adjoining deposit insurance regimes).

Many of the parameter estimates in the purchase and assumption regime are significantly different from their counterparts in the de facto TBTF regime (Column (2), Table 4). Together, the additional risk effects in the purchase and assumption regime are significant: The Wald test statistic for the additional effects on the traditional risk proxies jointly equaling zero was 59.4 compared to a critical value of 11.1 at the 5 percent confidence level. Importantly, the distribution of the additional joint risk effects calculated using the parameter estimates in column (2) and banking organization-specific values for the five risk proxies during the purchase and assumption regime has a fairly positive mean (1.73) with the vast majority of banking organizations (86\%) having a positive additional joint risk effect. And, the normalized marginal additional risk effect is positive (2.56). These findings mean that investors were significantly more sensitive to banking organizationspecific risks in the purchase and assumption period than they were in the de facto TBTF regime. This change in the market's sensitivity to banking organization-specific risks is also consistent with the view that "investors have rationally reflected changes in the government's policy toward 
Table 4:

Does the Deposit Insurance Regime Significantly Influence the Risk-Sensitivity of Issuance Spreads?

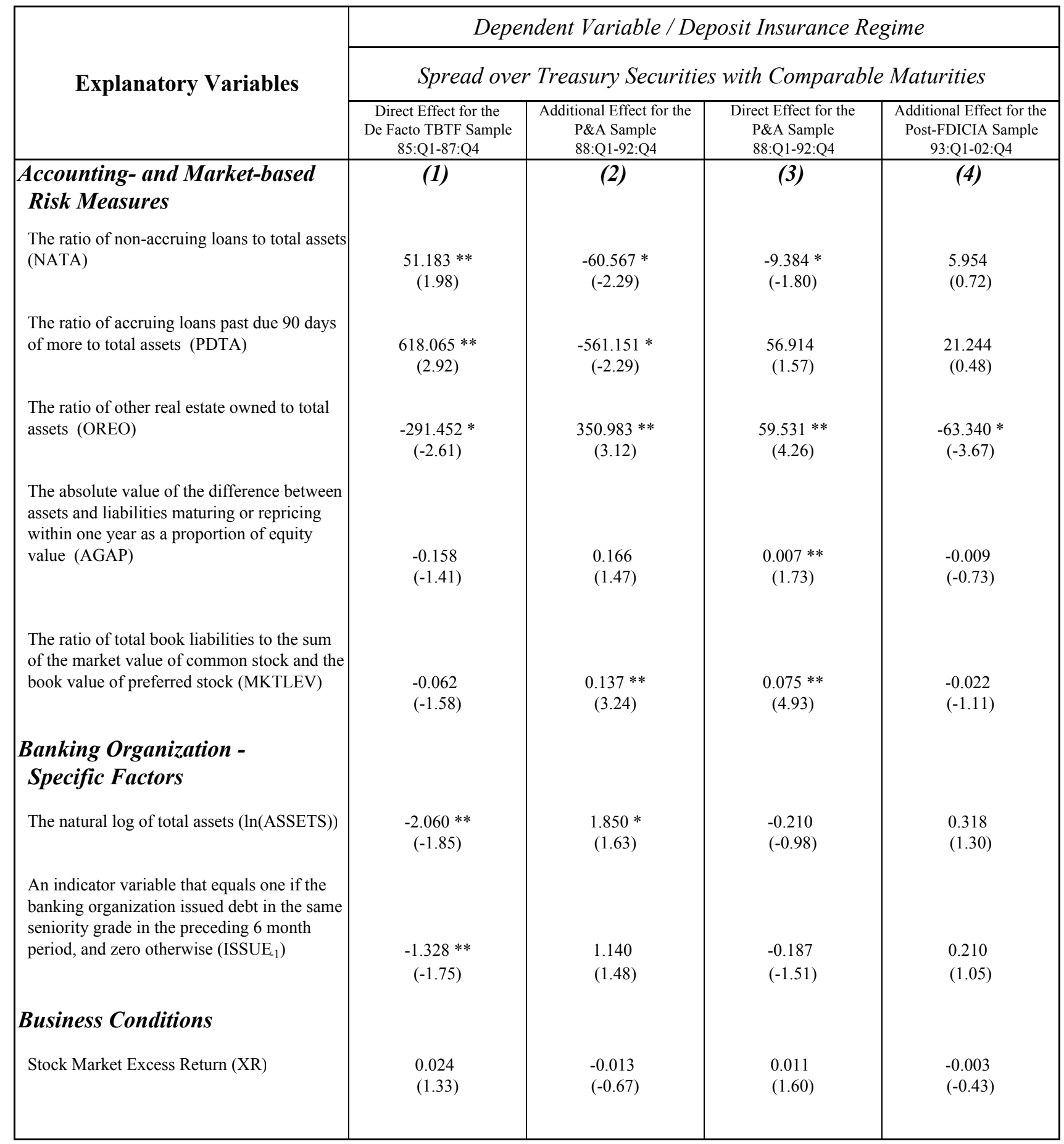

* Parameter estimates are statistically significant at the $10 \%$ level.

** Parameter estimates are statistically significant at the $10 \%$ level and have the predicted sign. 
Table 4 Continued

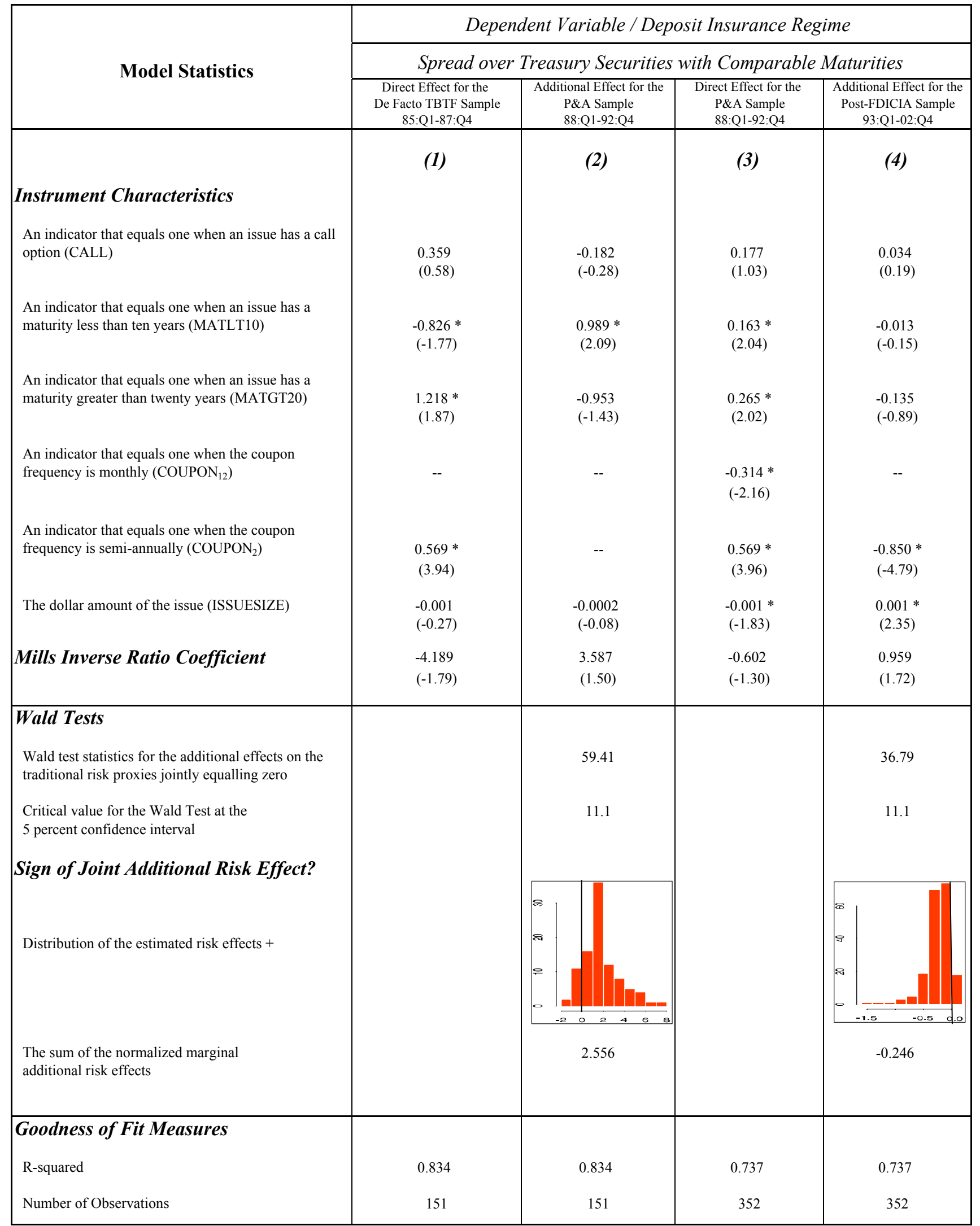

* Parameter estimates are statistically significant at the $10 \%$ level.

** Parameter estimates are statistically significant at the $10 \%$ level and have the predicted sign.

+ A vertical line appears at zero in each distribution of the estimated risk effects.

Note: All specifications include a constant term which was significant at the $5 \%$ level. Year indicator variables, which were equal to one in a specific year, and zero otherwise were also included. Observed spread regressions are heteroskedastic-consistent. $t$-statistics are in parenthes 
absorbing private losses in the event of bank failure.”68

The parameter estimates presented in column (4) of Table 4, imply that investors placed similar weights on the traditional risk proxies in the post-FDICIA (1993-2002) period as they did in the purchase and assumption (1988-1992) period. But, the additional effects on the traditional risk proxies in the post-FDICIA period were together significantly different from zero: The Wald test statistic for the additional effects on the traditional risk proxies jointly equaling zero was 36.8 compared to a critical value of 11.1 at the five percent confidence level. Because the sum of the normalized additional risk effects is negative (-0.246) and because $91 \%$ of the banking organizations have a negative additional estimated risk effect, it appears that there was an overall decrease in the risk sensitivity of subordinated debt spreads between the purchase and assumption (1988-1992) period and the post-FDICIA (1993-2002) period. As discussed more fully below, this finding is consistent with subordinated investors perceiving that prompt corrective actions by bank supervisors would likely reduce their expected losses in the event of a bank failure, despite their lower liquidation standing due to FDICIA and depositor preference rules.

\section{MARKET DISCIPLINE IN BANKING RECONSIDERED}

Several studies of banking organization subordinated debentures (e.g., Avery, Belton and Goldberg (1988), Gorton and Santomero (1990) and Flannery and Sorescu (1996)) found no statistical relationship between accounting-based measures of risk and secondary market subordinated debt prices prior to 1989, but did find such a relationship after 1989. Other studies using post-1989 secondary market data with similar empirical models (e.g., Jagtiani, Kaufman and Lemieux (2002) and DeYoung, Flannery, Lang and Sorescu (2001)) also found a significant positive correlation between banking organization-specific risk measures and subordinated debt prices. Because deposit insurance reforms were implemented beginning in the late 1980s, some maybe even most - observers took these findings as evidence that conjectural government guarantees prior to these reforms made subordinated debt investors insensitive to banking organization-specific risks.

In contrast, using information from the primary bond market during the 1985-1988 period,

\footnotetext{
${ }^{68}$ See Flannery and Sorescu (1996, p. 1347).
} 
we demonstrate that perceived government guarantees during that period did not make subordinated debt investors completely insensitive to bank-specific risks. Our sample selection model indicates that investors were able to rationally differentiate among the risks undertaken by major U.S. banking organizations. This result is consistent with early studies in the market discipline literature (Hannan and Hanweck (1988) and Ellis and Flannery (1992)) that found interest rates on relatively bankruptcy remote large certificates of deposit were sensitive to bank-specific risks.

This being said, our estimated lack of risk sensitivity of issuance decisions in the pre-1989 period would suggest that bond market investors were not sufficiently risk sensitive to ensure that the riskiest banks were significantly less likely to issue subordinated debt. In fact, we find that risky banks were no more or less likely to issue subordinated debt during the de facto TBTF (1985-1988) period. This result is consistent with investors being sensitive to banking organization-specific risks, but not being punitive enough to impose market discipline.

Importantly, our finding that risky banks were no more or less likely to issue subordinated debt during the de facto TBTF (1985-1988) period is inconsistent with the conventional view that subordinated investors were insensitive to banking organization-specific risks. Had conjectural guarantees been that large, or that certain, the most risky banking organizations would have been more likely to issue subordinated debt during the de facto TBTF period. This example clearly demonstrates why it is important to consider not only the risk-sensitivity of debt holders (i.e., the demand-side of the debt market), but also the risk-sensitivity of funding decisions (i.e., the supplyside of the debt market) to gauge the effects of conjectural government guarantees.

Using the same issuance decision and sample selection models and the same methods for signing the joint risk effect across different deposit insurance regimes, we find the strongest risksensitivity of subordinated debt issuance spreads during the purchase and assumption (1988-1992) regime - a period when bank regulators reduced protections for large bank holding companies’ creditors. ${ }^{69}$ During this period, the risk-sensitivity of these spreads for banking organizations was sufficiently strong to ensure that the riskiest banks were less likely to issue subordinated debt. This finding implies that the debt market was punitive enough to influence managerial actions (i.e., subordinated debt issuance decisions). And the action being taken (i.e., not issuing suobordinated

\footnotetext{
${ }^{69}$ Flannery and Sorescu (1996) also found market discipline to be particularly strong during this period.
} 
debt), ceteris paribus implied a reduction in leverage and thus a reduction in bank risk. In other words, subordinated debt investors appeared to have done more than merely monitor changes in banking organization conditions: They influenced managerial actions in a manner consistent with market discipline.

Interestingly, in the post-FDICIA (1993-2002) period, the risk-sensitivity of issuance spreads appears to have waned a bit. Using sample selection models, the distribution of estimated joint risk effects was more tightly distributed near zero in the post-FDICIA (1993-2002) period (rightmost column, Table 3) than it was during the purchase and assumption (1988-1992) period (middle column, Table 3), the mean of the distribution of joint risk effects was smaller in the post-FDICIA period than it was during the purchase and assumption period, and the parameter estimate on the principal component during the post-FDICIA period was about a quarter of the size of the corresponding parameter estimate for the purchase and assumption period. Estimation of the additional effects for the traditional risk proxies for the post-FDICIA (1993-2002) period compared with the purchase and assumption (1988-1992) period confirmed that such additional effects were negatively significant. Together, these findings are consistent with the view that investors have taken seriously regulatory reforms that were tailored to limit the size of the safety net by increasing the losses borne by holding company subordinated debt holders in the event that their firm's subsidiary financial institutions fail, as well as reforms that are designed to limit potential losses given a default (e.g., prompt corrective actions). Our findings suggest that the resulting default premia contained in subordinated debt spreads have in part reflected investors' expectations with respect to these somewhat offsetting objectives. ${ }^{70}$ Nevertheless, our results indicate that the risksensitivity of subordinated debt spreads remained sufficiently strong to ensure that the riskiest banks were less likely to issue subordinated bonds. That is, investors remained risk sensitive enough to be punitive enough to continue to impose market discipline.

Our findings also suggest that market discipline has similar effects on banking organizations as it does on other corporate entities. In particular, we demonstrate that issuance decisions for banking organizations are sensitive to firm-specific risks, just as others have found for non-financial

\footnotetext{
${ }^{70}$ The post-FDICIA period was also a period of unprecedented prosperity and good banking conditions. Therefore, there has not yet been a harsh test for the effectiveness of PCA and depositor preference rules.
} 
firms (Castanias (1983), Marsh (1982)). Consistently, Morgan and Stiroh (1999) find that the risksensitivity of bank bond spreads is about the same as the risk-sensitivity of corporate bond spreads.

The foregoing discussion demonstrates that the funding decision gauge for managerial actions has several advantages over those previously used in the banking market discipline literature. First, it can be measured without noise. Second, it is clearly the result of an explicit decision by bank management. And third, it is, ceteris paribus, an action that implies a reduction in leverage and a corresponding reduction in bank risk.

In sum, our empirical evidence indicates that market discipline is currently exerted on U.S. banking organizations in the primary subordinated debt market. Put differently, investors can and do monitor and influence banking organizations even in the absence of a formal mandatory subordinated debt policy. Our results also suggest that tests for the risk-sensitivity of secondary market debt spreads could be influenced by funding manager decisions that are sensitive to banking organization-specific risks. For example, if the riskiest banking organizations never issued subordinated debt because of the punitiveness of the bond market, then no secondary market subordinated debt prices would exist for these firms. In this case, the sample selection problems for issuance and secondary market spread analyses would be identical. This remains an important issue for further study, since many researchers have used secondary market spreads to test for market discipline, and bank supervisors and market participants monitor the secondary subordinated debt market spreads of large U.S. banking organizations. 


\section{REFERENCES}

Amihud, Y. and H. Mendelson, 1991, "Liquidity, Maturity, and the Yields on U.S. Treasury Securities,” Journal of Finance, 46, September, pp. 1411-1425.

Avery, R. B., T.M. Belton, and M.A. Goldberg, 1988, "Market Discipline in Regulating Bank Risk: New Evidence from the Capital Markets," Journal of Money, Credit, and Banking, November, pp. 547-610.

Barro, R. J., 1990, “The Stock Market and Investment,” The Review of Financial Studies, March, 115-131.

Basel Committee on Banking Supervision, 2001, Pillar 3 (Market Discipline): Supporting Document to the New Basel Capital Accord, Bank for International Settlements: Basel, Switzerland, January.

Beim, D. O., 1992, “Estimating Bond Liquidity,” Working Paper, Columbia First Boston Series in Money, Economics, and Finance, FB-9208, April.

Berger, A.N., R.J. Herring, and G.P. Szegö, 1995, “The Role of Capital in Financial Institutions,” Journal of Banking and Finance, 19, June, pp. 393-430.

Bikhchandani, S., D. Hirshleifer, and I. Welch, 1998, "Learning from the Behavior of Others: Conformity, Fads, and Informational Cascades," Journal of Economic Perspectives, 12, Summer, pp. 151-171.

Birchler, U. and D. Hancock, 2004, "What Does the Yield on Bank Subordinated Debt Measure?, Finance Economics Discussion Series (FEDS) Working Paper, 2004-19, Board of Governors of the Federal Reserve System April.

Black, F. and J.C. Cox, 1975, "Valuing Corporate Securities: Some Effects of Bond Indenture Provisions, The Journal of Finance, 31 (2), December, pp. 351-167.

Bliss, R. R. and M. J. Flannery, 2001, "Market Discipline in the Governance of U.S. Bank Holding Companies: Monitoring versus Influencing," in Prudential Supervision: What Works and What Doesn’t, edited by F.S. Mishkin, Chicago: University of Chicago Press, pp. 107-146.

Board of Governors of the Federal Reserve System, 1999a, "Capital Adequacy Guidelines," Washington, DC, May.

Board of Governors of the Federal Reserve System, 1999b, "Using Subordinated Debt as an Instrument of Market Discipline,” Staff Study, Study Group on Subordinated Notes and Debentures, December. 
Board of Governors of the Federal Reserve System and United States Department of the Treasury, 2000, The Feasibility and Desirability of Mandatory Subordinated Debt, Report to Congress pursuant to section 108 of the Gramm-Leach-Bliley Act of 1999, December.

Boardman, C.M. and R.W. McEnally, 1981, “Factors Affecting Seasoned Corporate Bond Prices, Journal of Financial and Quantitative Analysis, 16, June, pp. 207-226.

Calomiris, C.W., 1997, The Postmodern Bank Safety Net: Lessons from Developed and Developing Countries, American Enterprise Institute: Washington: D.C.

Calomiris, C.W., 1998, "Building an Incentive-Compatible Safety Net,” Journal of Banking and Finance, 23, pp. 1499-1519.

Castanias, R., 1983, “Bankruptcy Risk and Optimal Capital Structure,” Journal of Finance, 38, pp. 1617-1635.

Chordia, T., R. Roll, and A. Subrahmanyam, 2001, “Market Liquidity and Trading Activity,” The Journal of Finance, 56, April, pp. 501-530.

Chordia, R., A. Sarkar, and A. Subrahmanyam, 2001, “An Empirical Analysis of Stock and Bond Market Liquidity,” Working Paper, Anderson Graduate School of Management, University of California at Los Angeles, May 5.

Cooper, K. and D.R. Fraser, 1988, “The Rising Cost of Bank Failures: A Proposed Solution,” Journal of Retail Banking, vol. 10, Fall, pp. 5-12.

Covitz, D. M., D. Hancock, and M. L. Kwast, 2000, “Mandatory Subordinated Debt: Would Banks Face More Market Discipline?,” mimeo, Board of Governors of the Federal Reserve System, December.

Covitz, D.M., D. Hancock, and M.L. Kwast, 2004, "A Reconsideration of the Risk Sensitivity of U.S. Banking Organization Subordinated Debt Spreads: A Sample Selection Approach,” FRBNY Economic Policy Review, forthcoming.

Covitz, D. M., and P. Harrison, 2003, “Do Banks Strategically Time Public Bond Issuance Because of the Accompanying Disclosure, Due Dilligence, and Investor Scrutiny?,” Journal of Financial Intermediation, forthcoming.

DeYoung, R., M.J. Flannery, W.W. Lang, S.M. Sorescu, 2001, “The Information Content of Bank Exam Ratings and Subordinated Debt Prices,” Journal of Money, Credit, and Banking, 33, November, pp. 900-925.

Diamond, D.W., 1991, "Monitoring and Reputation: The Choice Between Bank Loans and DirectlyPlaced Debt,” Journal of Political Economy, 99(4), 689-721. 
Ellis, D.M. and M.J. Flannery, 1992, “Does the Debt Market Assess Large Banks’ Risk?,” Journal of Monetary Economics, December, pp.481-502.

Elton, E.J., M.J. Gruber, D.Agrawal, C. Mann, 2000, “Explaining the Rate Spread on Corporate Bonds, The Journal of Finance, 56 (1), February, pp. 247-277.

English, W.B., 1999, “The Value of SND Requirements for Limiting Bank Risk Taking -- A Theoretical Note,” Working Paper, Board of Governors of the Federal Reserve System, December.

Evanoff, D.D., 1993, “Preferred Sources of Market Discipline,” Yale Journal on Regulation, vol. 10, pp. 347-67.

Evanoff, D.D. and L.D. Wall, 2000, “Subordinated Debt as Bank Capital: A Proposal for Regulatory Reform,” Economic Perspectives, Federal Reserve Bank of Chicago, Second Quarter.

Fama, E. F., 1981, “Stock Returns, Real Activity, Inflation, and Money,” The American Economic Review, 71, pp. 545-565.

Fama, E.F. and K.R. French, 1993, "Common Risk Factors in the Returns on Stocks and Bonds," Journal of Financial Economics, 33, pp. 3-56.

Fischer, S. and R.C. Merton, 1984, "Macroeconomics and Finance: The Role of the Stock Market," Carnegie-Rochester Conference Series on Public Policy, pp. 57-108.

Fisher, L., 1959, “Determinants of Risk Premiums on Corporate Bonds,” Journal of Political Economy, 67, June, pp. 217-237.

Fisher, M., D. Nychja, and D. Zervos, 1994, "Fitting the Term Structure of Interest Rates with Smoothing Splines,” Working Paper, Board of Governors of the Federal Reserve System, September.

Flannery, M. J., 1998, “Using Market Information in Prudential Bank Supervision: A Review of the U.S. Empirical Evidence, Journal of Money, Credit, and Banking, 30 (3), August, pp. 273305.

Flannery, M. J. And J.F. Houston, 1999, “The Value of a Government Monitor for U.S. Banking Firms, Journal of Money, Credit and Banking, February, pp. 14-34.

Flannery, M..J. and S.M. Sorescu, 1996, "Evidence of Bank Market Discipline in Subordinated Debenture Yields: 1983-1991,” Journal of Finance, 51, September, pp. 1347-1377.

Gorton, G. and A.M. Santomero, 1990, “Market Discipline and Bank Subordinated Debt,” Journal of Money, Credit and Banking, February, pp. 119-128.

Goyal, V. K., 2001, “Market Discipline of Bank Risk: Evidence from Subordinated Debt Contracts,” 
Working Paper, Department of Finance, Hong Kong University of Science and Technology, October.

Hancock, D. and M.L. Kwast, 2001, "Using Subordinated Debt to Monitor Bank Holding Companies: Is it Feasible?,” Journal of Financial Services Research, 20, October-December, pp. 147-187.

Hannan, T. and G.A. Hanweck, 1988, "Bank Insolvency Risk and the Market for Large Certificates of Deposit,” Journal of Money, Credit, and Banking, May, pp. 575-593.

Harris, M., and A. Raviv, 1991, “The Theory of Capital Structure,” Journal of Finance, 46, March, pp. 297-355.

Harrison, P., 2001, “The Impact of Market Liquidity in Times of Stress on the Corporate Bond Market: Pricing, Trading, and the Availability of Funds During Heightened Illiquidity,” mimeo, Board of Governors of the Federal Reserve System, August.

Hassan, M.K., 1993, “Capital Market Tests of Risk Exposure of Loan Sales Activities of Large U.S. Commercial Banks,” Quarterly Journal of Business and Economics, Winter, pp. 27-49.

Hassan, M.K., G.V. Karels, M.O. Peterson, 1993, “Off-Balance-Sheet Activities and Bank DefaultRisk Premia: A Comparison of Risk Measures,” Journal of Economics and Finance, Fall, pp. 69-83.

Heckman, J. A., 1979, “Sample Selection Bias as a Specification Error,” Econometrica, 47, pp. 153162.

Jagtiani, J., G. Kaufman, C. Lemieux, 2002, “The Effect of Credit Risk on Bank and Bank Holding Company Bond Yields: Evidence from the Post-FDICIA Period,” Journal of Financial Services Research, 25, pp. 559-575.

James, C.M., 1988, “The Use of Loan Sales and Standby Letters of Credit by Commercial Banks, Journal of Monetary Economics, 22, pp. 395-422.

James, C.M., 1990, “Heterogeneous Creditors and the Market Value of Bank LDC Loan Portfolios,” Journal of Monetary Economics, 25, pp. 325-346.

Jones, D.J. and K.K. King, 1995, “The Implementation of Prompt Corrective Action: An Assessment,” Journal of Banking and Finance, 19, pp. 491-510.

Jung, K., Y. Kim, and R. M. Stulz, 1996, “Timing, Investment Opportunities, Manaagerial Discretion, and the Security Issue Decision,” Journal of Financial Economics, 42, pp. 159185.

Kamara, A., 1994, “Liquidity, Taxes, and Short-Term Treasury Yields,” Journal of Financial and 
Quantitative Analysis, 29, September, pp. 403-417.

Keeley, M.C., 1990, “Deposit Insurance, Risk, and Market Power in Banking,” American Economic Review, 80, pp. 1183-1200.

Killingsworth, M. R., 1983, Labor Supply, Cambridge: Cambridge University Press.

Lamont, O., 2000, “Investment Plans and Stock Returns,” Journal of Finance,55, pp. 2719-2745.

Lang, W.W., and D. Robertson, 2000, “Analysis of Proposals for a Minimum Subordinated Debt Requirement, Working Paper, Office of the Comptroller of the Currency, March.

Levonian, M., 1999, “Can Subordinated Debt Enhance Market Discipline in Banking?,” Working Paper, Federal Reserve Bank of San Francisco, October.

MacKay, P. and G.M. Phillips, 2002, “Is There an Optimal Industry Financial Structure?,” Working Paper, University of Maryland, June 11.

MacKie-Mason, J.K., 1990, “Do Taxes Affect Corporate Financing Decisions?,” The Journal of Finance, 45, pp. 1471-1493.

Marsh, P., 1982, “The Choice Between Equity and Debt: An Empirical Study,” Journal of Finance, 37, pp. 121-144.

Mergent Bond Record, 1984-2001, Mergent FIS, Inc., 60 Madison Ave, New York.

Merton, R.C., 1977, "An Analytic Derivation of the Cost of Deposit Insurance and Loan Guarantees: An Application of Modern Option Pricing Theory,” Journal of Banking and Finance, 1, pp. 3-11.

Meyer, L.H., 1999, "Market Discipline as a Complement to Bank Supervision and Regulation,” Remarks Before the Conference on Reforming Bank Capital Standards, Sponsored by Ernst \& Young and AEI-Brookings Joint Center on Regulatory Studies, Council on Foreign Relations, New York, New York, June 14.

Morgan, D.P. and K.J. Stiroh, 1999, "Bond Market Discipline of Banks: Is the Market Tough Enough?, Working Paper 95, Federal Reserve Bank of New York, December.

Morgan, D.P. and K.J. Stiroh, 2001, "Market Discipline of Banks: The Asset Test,” Journal of Financial Services Research, 20, November, pp. 195-208.

Pennacchi, George, 2001, “Comments on Morgan and Stiroh,” Journal of Financial Services Research, 20, November, pp. 209-211.

Sarig, O. and A. Warga, 1989, “Bond Price Data and Bond Market Liquidity,” Journal of Financial 
and Quantitative Analysis, 24, September, pp.367-378.

U.S. Shadow Regulatory Committee, 2000, "Reforming Bank Capital Regulation: A Proposal by the U.S. Regulatory Committee,” The AEI Press, March.

Wall, L. D., 1989, “A Plan for Reducing Future Deposit Insurance Losses: Putable Subordinated Debt, Economic Review, Federal Reserve Bank of Atlanta, July/August, pp. 2-17.

Warga, A.D., 1991, “Corporate Bond Price Discrepancies in the Dealer and Exchange Markets,” Journal of Fixed Income, 1, December, pp. 7-16.

Welch, I., 2002, “Columbus’ Egg: Stock Returns are the Main Determinant of Capital Structure,” Working Paper, Yale International Center for Finance, No. 02-03, May 16.

White, H., 1980, “A Heteroskedasticity-Consistent Covariance Matrix and a Direct Test for Heteroskedasticity,” Econometrica, 48, pp. 721-746. 